\title{
Systematically quantifying morphological features reveals constraints on organoid phenotypes
}

Lauren E. Beck ${ }^{1}$, Jasmine Lee ${ }^{1}$, Christopher Coté ${ }^{1}$, Margaret C. Dunagin ${ }^{1,2}$, Nikkita Salla ${ }^{1}$, Marcello K. Chang ${ }^{1}$, Alex J. Hughes ${ }^{1,3}$, Joseph D. Mornin ${ }^{4}$, Zev J. Gartner,6,7, Arjun Raj ${ }^{1,2, *}$

${ }^{1}$ Department of Bioengineering, School of Engineering and Applied Sciences, University of Pennsylvania, Philadelphia, PA, USA

${ }^{2}$ Department of Genetics, Perelman School of Medicine, University of Pennsylvania, Philadelphia, PA, USA

${ }^{3}$ Department of Cell and Developmental Biology, Perelman School of Medicine, University of Pennsylvania, Philadelphia, PA, USA

${ }^{4}$ Independent Researcher, Berkeley, CA, USA

${ }^{5}$ Department of Pharmaceutical Chemistry, University of California, San Francisco, San

Francisco, CA, USA

${ }^{6}$ Center for Cellular Construction, University of California, San Francisco, San

Francisco, CA, USA

${ }^{7}$ Chan Zuckerberg Biohub, San Francisco, CA, USA

${ }^{*}$ Correspondence to arjunrajlab@gmail.com

\begin{abstract}
Organoids recapitulate complex 3D organ structures and represent a unique opportunity to probe the principles of self-organization. While we can alter an organoid's morphology by manipulating the culture conditions, the morphology of an organoid often resembles that of its original organ, suggesting that organoid morphologies are governed by a set of tissue-specific constraints. Here, we establish a framework to identify constraints on an organoid's morphological features by quantifying them from microscopy images of organoids exposed to a range of perturbations. We apply this framework to Madin-Darby Canine Kidney cysts and show that they obey a number of constraints taking the form of scaling relationships or caps on certain parameters. For example, we found that the number, but not size, of cells increases with increasing cyst size. We also find that these constraints vary with cyst age and can be altered by varying the culture conditions. This quantitative framework for identifying constraints on organoid morphologies may inform future efforts to engineer organoids.
\end{abstract}




\section{Introduction}

Organoids are 3D structures that grow entirely in vitro from single or small groups of cells that mimic organ anatomy. Organoids have the potential to transform both personalized and regenerative medicine, since thousands of organoids can be grown under controlled conditions in vitro from small amounts of donor tissue. It is clear that organoids can form intricate biological structures, and these structures have an overall structure that resembles the associated organ. Yet, at the same time, there is often enormous variability between individual organoids (Garreta et al. 2020; Koo et al. 2019; Phipson et al. 2019; Kim, Koo, and Knoblich 2020; Volpato et al. 2018), and changing the organoid culture protocol can similarly lead to large changes (Yin et al. 2014; Sidhaye and Knoblich 2020; Gjorevski et al. 2016). Thus, the question remains as to what constraints organoids obey to give rise to the aspects of their morphology that are immutable, and what aspects of their morphology are either variable or tunable. Categorizing organoid features in this way may help reveal the design principles underlying organoid development.

One way to formalize the concept of constraints is via the dimensionality of morphospace, which is the set of morphologies an organism or model system can have. If one were to measure all possible features of an organoid's morphology (e.g. size, number of nuclei, together comprising the axes of an organoid's morphospace) across a large enough number of organoids, it could be that a large number of these features would strongly covary and thus could be explained by a single variable. For example, if size and number of nuclei were to be strongly correlated, then the dimensionality would effectively be 1 instead of 2, and the relationship between these variables would constitute a constraint on organoid morphology. On the other hand, if variables show a lack of correlation, then that would suggest independent axes of variability, indicating an additional degree of freedom in organoid morphospace. Examples of such dimension reduction have been demonstrated in both $C$. elegans and Snapdragon flowers, four dimensions capture over $90 \%$ of the variance in morphologies (Stephens et al. 2008; Cui et al. 2010). However, such analyses have not been performed in organoids yet. Recent work has quantitatively described brain organoid morphologies (Albanese et al. 2020) and uncovered genetic interactions governing intestinal organoid morphologies (Lukonin et al. 2020), but the constraints on organoid morphologies have not been characterized.

One potential reason that there are few quantitative analyses of organoid morphologies is that previous studies have been limited to a small set of two-dimensional features, such as organoid area and nuclear intensity, that fail to fully capture many 
characteristic aspects of the organoid's shape (Kassis et al. 2019; Gracz et al. 2015). A major challenge is that quantifying morphological features such as the number of cells, cell shapes, etc., often requires microscopy images be annotated to outline each individual cell or nucleus. While algorithms for automatic segmentation for images of large three-dimensional structures are improving (Piccinini et al. 2020), in many instances, segmentation must still be done manually to ensure sufficient accuracy. Such issues are compounded in organoids with many cell types and complex three-dimensional structures that are difficult to quantitatively align and compare to each other. Simpler "model" organoid systems might serve as a proving ground to test concepts about morphospaces.

How might we characterize the constraints on organoid morphologies? Our approach was to use variation in organoid morphology - both naturally occurring and variation induced by external stimuli-to sample the organoid morphospace. As a proof of concept, we developed this approach in spherical cysts grown from Madin-Darby Canine Kidney (MDCK) cells. We then quantified morphological features (cyst size, number of cells, eccentricity, etc) and the relationships between them (how does the number of cells scale with cyst size), thus revealing the constraints on MDCK cyst morphologies. To overcome the challenge of systematically quantifying morphological features, we combined algorithms for generating candidate annotations with software that allowed for quick manual correction. We found that MDCK cyst morphologies all fell along a small set of dimensions. These dimensions encoded a number of constraints; for instance, larger cysts had increased number but not size of constituent cells. We also found that some of these constraints on MDCK cyst morphologies vary with age and can be perturbed through drugs and growth factors. Our results demonstrate a general strategy for determining the ways in which organoid morphologies are either constrained or free to vary.

\section{Results}

\section{MDCK cyst morphologies span a limited number of dimensions}

To quantify constraints on cyst morphologies, we designed an experimental and analytical workflow for culturing cysts, performing 3D imaging, annotating structures of interest, and measuring morphological features (Fig. 1A). We chose to apply this approach to MDCK cysts because of their relative simplicity and because they are amenable to high magnification 3D imaging. MDCK cells are an immortalized epithelial line that grow in adherent culture on 2D substrates, but form hollow 3D cysts when cultured in 3D matrices such as collagen or Matrigel (Supp. Fig. 1). A MDCK cyst 
grows from a single cell and is composed of an outer layer of polarized cells surrounding one to many lumens. The combination of their simplicity with the existence of a number of structural features to quantify make MDCK cysts an ideal system for establishing a framework for quantifying constraints on organoid morphologies.

(We evaluated other organoid systems, such as the gut organoids, for our analysis, but found that the complexity of their morphologies presented a much larger challenge. For instance, gut organoids have complex bud structures that one would need to align to each other for quantitative comparison. The comparative simplicity of MDCK cysts that are at least nominally spherical made our analysis feasible as a proof of principle, with MDCK cysts serving as a model for more complex organoids.)

In order to quantify 3D measurements of morphological features for hundreds of MDCK cysts, we established a pipeline for semi-automatically annotating cyst structures (nuclei, lumens, and cyst boundary). To identify the lumen and cyst boundaries, we developed a custom analysis pipeline that generated candidate annotations and accepted manual corrections to the annotations as needed (Supp. Fig. 2). We used cellpose (Stringer et al. 2020) to identify the boundaries of each nucleus and a custom analysis pipeline to manually correct the 3D annotations (Supp. Fig. 3). Due to depth of field limitations, in many cases we could not image the full depth of the cyst. We thus made sure to image at least the bottom half of the cyst, from which we computationally determined the middle point of each cyst and measured features on only the bottom half of each cyst to ensure a fair comparison between all cysts. We then measured morphological features of size, shape, and number on the nuclei, lumen, and cyst annotations anticipating that these may be the features that vary amongst cysts (Table 1). We performed a variety of comparisons between morphological features in order to verify that our measurements were consistent with basic geometric constraints. For example, because the cysts always appeared spherical, we confirmed that the cyst volume scaled with the cube of the cyst radius (Supp. Fig. 4). We also confirmed that the total lumen and total nuclear volume was always less than that of the cyst volume, and we visually inspected cysts with high and low feature metrics to confirm that the quantified differences reflected differences in the images (Supp. Fig. 5-6).

We then wanted to find relationships between features that could potentially reflect biological constraints. For example, did the number of cells scale with the size of the cyst? Or, did larger cysts have the same number of cells as smaller cysts, but with larger component cells? We used the number of nuclei as a proxy for the number of cells and found that larger cysts had proportionally more nuclei (Fig. 1B). Because cells peripheral to the lumen(s) had different morphology than those internal to the lumens, 
we wondered whether their number scaled differently with cyst volume. We found that the number of peripheral nuclei scaled sublinearly with cyst volume (Supp. Fig. 7). Surprisingly, the number of internal cells scaled superlinearly with cyst volume, thus ensuring that the total number of cells scaled linearly with cyst volume. Given that the number of cells scaled with the cyst volume, we predicted that cell size should be independent of cyst size. We found that despite increases in cyst volume the peripheral cell height and width are constant at $\sim 12 \mu \mathrm{m}$ and $\sim 15 \mu \mathrm{m}$, respectively (Fig. $1 \mathrm{C}-\mathrm{D})$. Together, we called this set of constraints the constant-cell-density constraint.

We also wondered how lumens, both in number and size, scaled with increasing cyst size. For example, if a cyst is larger must it also have larger lumens? One alternative is that there is maximum lumen size, and larger cysts then have multiple lumens of the same size as smaller cysts. We found that the total lumen volume increased with increasing cyst volume, but that this could be achieved through one large lumen or many smaller lumens (Fig. 1E-G). However, we did notice that there was seemingly a maximum number of lumens per cyst that increased linearly with cyst volume. We called this constraint the "lumen number cap", and its existence suggests that there may be a minimum lumen size (Supp. Fig. 8).

Given that MDCK cysts obey a number of constraints, we then wondered whether these constraints are coupled. In other words, might there be a single dimension (or a few dimensions), each of which may comprise several correlated features, along which all MDCK cyst morphologies fall (Fig. 1H)? To identify dimensions in the space of MDCK cyst morphologies we performed principal component analysis (PCA) on the set of 77 cysts and their 66 morphological features. In order to apply PCA to our data, we needed to supply a single value for each feature for each cyst. For all features describing nuclei we used both the mean and standard deviation across all nuclei within the cyst, e.g. mean nuclear volume and standard deviation of nuclear volume. For features describing lumens we used the mean across all lumens in the cyst, e.g. mean lumen volume. We didn't include other higher order statistics like standard deviation because it was impossible to do so for the many cysts that had only one lumen. We found that the first three principal components respectively explain $30 \%$, $19 \%$, and $10 \%$ of the variation in MDCK cyst morphologies (Fig. 1I). We then wondered whether the principal components reflected any of the constraints we had previously identified. We found that the first principal component represented lumen size and inversely nuclear size, reflecting the fact that as lumens get larger, nuclei get smaller (Fig. 1J-L, Supp. Fig. 9). The second principal component represents cyst size and number of nuclei, reflecting that increased cyst size was associated with increased number of nuclei, a relationship we previously identified as the constant-cell-density 
constraint. The third principal component represented the trade-off between lumen size and the number of lumens, reflecting that, for a given cyst size, in order to have more lumens, the individual lumens must be smaller (rather than there is a maximum lumen size which is independent of the number of lumens). The third principal component also represented a trade-off between nuclear size and the density of nuclei, reflecting that, for a given cyst size, in order to have more nuclei the nuclei must be smaller (Supp. Fig. 10). (Consistent with PC1, we also found that nuclear size anti-correlated with lumen size.) Beyond those three principal components, the remaining components accounted for less variation than components calculated from randomized data, suggesting that those PCs likely do not reflect substantial variation in the data. Thus, despite quantifying a large number of features, MDCK cyst morphologies can thus be represented by a limited number of dimensions.

\section{Constraints on MDCK cyst morphologies vary with age}

MDCK cysts grow continuously over the course of weeks, from a single cell into large cysts. To determine whether or not cyst age affects the constraints on MDCK cyst morphologies, we compared the quantitative relationship between various features for cysts of different ages. We partitioned our data based on cyst age, ranging from 3-17 days of growth. Using the same imaging and feature quantification described above, we saw that, as expected, old cysts were larger in volume on average (Fig. 2A-B). We also noticed that, for a given age, there was a spread in cyst sizes. This variation in size enabled us to compare constraints in cyst size across different age categories (Fig. 2C). We used cysts cultured for 9 days as a reference point for younger and older cysts to evaluate how constraints on MDCK cyst morphologies changed with cyst age.

We first wondered if the constant-cell-density constraint varied for cysts of different ages (Fig. 2D, Supp. Fig. 11). We found that cysts grown for 7-11 days obeyed the constant-cell-density constraint on the number of nuclei and cyst volume. However, cysts cultured for 3-5 or 13-17 days did not obey this constraint-they had fewer nuclei per cyst volume. Interestingly, while older cysts are generally bigger, for older cysts that are small for their age, the number of nuclei for a given volume was similar to that of middle aged cysts. This size-dependent change suggests that the decrease in the cell density in older cysts may be more dependent on these older cysts having reached a certain threshold volume rather than the age of the cyst per se. We looked at the age dependence of the cell size component of the constant-cell-density constraint (Fig. 2E, Supp. Fig. 12). We found that younger cysts did not obey the same constraint as cysts culture for 9 days, instead they had larger cells per cyst volume. 
Having established that at least one constraint on MDCK cyst morphologies is age-dependent, we wondered whether other constraints were similarly affected by age. We looked at the age dependence of the lumen-number-cap constraint (Fig. 2F, Supp. Fig. 13). We found that both younger and older cysts obeyed different constraints than cysts cultured for 9 days: cysts cultured for 3 days had a higher maximum number of lumens per cyst volume, and cysts cultured for 13-17 days had a lower maximum number of lumens per cyst volume. The decrease in the number of lumens as cysts age beyond 9 days suggests that multiple lumens in a cyst are either merging or disappearing as cysts grow older. In summary, both the constant-cell-density and lumen-number-cap constraints were not fixed throughout the cyst lifetime but rather varied with age.

Drug and environmental perturbations can change constraint parameters but do not break them

Having found constraints on MDCK cyst morphologies, we wondered whether these constraints applied to cysts whose morphology we perturbed using exogenous agents. For example, if we perturb the cysts with a drug which makes the cysts larger, will the same constant-cell-density constraint still apply? If not, there are two ways that the constraint could be disobeyed. One is that the perturbed cysts could follow the same constraint but with different parameters, for example, by changing the slope of the relationship between cell number and cyst volume. Alternatively, a perturbation could qualitatively remove a constraint and decouple, for example, the number of nuclei and cyst volume. Either of these possibilities would suggest that the constraints on MDCK cyst morphologies are context-specific.

There are few references to drugs which modify the morphology of MDCK cysts in the literature. Thus, to identify drugs that change MDCK cyst morphologies we designed a high-throughput drug screen of small molecule drugs from Selleck Chemicals Bioactive Compound library. This library contains $\sim 2,000$ small molecule drugs including kinase and epigenetic inhibitors as well as ion channel, metabolic, and cancer compounds. To conduct the screen, we plated MDCK cells in 384-well plates, added $1 \mu \mathrm{M}$ of each drug, and allowed the cells to grow into cysts for seven days, at which point the cysts were fixed and imaged. We then quantified the area of each cyst and the average across cysts for each perturbation. We found that, while most drugs did not appear to change the area of the cyst relative to controls, there were many drugs which made the cysts smaller or larger (Fig. 3A). We considered "hits" for larger cysts to be the drugs that were on both the list of the top 100 drugs as ranked by fold change and the list of the top 100 drugs as ranked by z-score, a total of 78 drugs. We found 80 "hits" for 
smaller cysts using the same approach. We found that hits that resulted in smaller cysts were enriched for drugs in the kinase, epigenetic, and cancer categories, while hits for larger cysts were enriched for kinases, cancer, and G protein-coupled receptor categories (Supp. Fig. 14). To gauge how many of our hits may have arisen by chance, we screened a portion (1/7th) of the drug library again. We found that there was a correlation $(r=0.63)$ between the fold change in cyst area from the screen and this targeted replication, suggesting that the majority of our hits were not random (Supp. Fig. 15). The screen hits represented potential candidates for perturbing MDCK cyst morphologies and then asking whether perturbed MDCK cysts obey the same constraints as unperturbed cysts.

We further grouped hits for smaller and larger cysts according to their targets (Supp. Table 3-4). We selected four drugs from our list of hits from the screen that increased cyst size from groups targeting mammalian target of rapamycin, aurora kinase, phosphodiesterase, and serotonin. Similarly, we selected three drugs that made cysts smaller from groups targeting epidermal growth factor receptor, histone deacetylases, and exportin-1. We additionally used idelalisib, an inhibitor of the delta form of phosphoinositide 3-kinase shown to affect MDCK cyst polarity (Peng et al. 2015), and oratinib, an inhibitor of platelet-derived growth factor receptor. We plated MDCK cells to form cysts, immediately added these drugs at a range of concentrations, and then grew the cysts for 9 days (Table 2). Additionally, we tested a non-drug perturbation (cell seeding density) by culturing MDCK cysts with a higher initial cell density (the concentration of the cells when seeding the cysts). We then fixed, stained, and imaged the perturbed cysts as described above, after which we measured the same set of morphological features (Fig. 3B-C). We found that the screen hits that we expected to make cysts smaller did indeed lead to smaller cysts, but none of the ones predicted to make them larger did so. We found that increased seeding density had no effect on the size of the cysts.

We then wondered whether perturbed cysts obeyed the same constant-cell-density and lumen-number-cap constraints as unperturbed cysts. We found that, with the exception of two drugs (selinexor and sumatriptan succinate), perturbed cysts obeyed the same constant-cell-density constraint as unperturbed cysts (Fig. 3D-E). Cysts perturbed with sumatriptan succinate (a serotonin receptor inhibitor) had more nuclei per given cyst volume than any age of unperturbed cysts, while cysts perturbed with selinexor (an exportin-1 inhibitor) had larger nuclei per given cyst volume. Notably, the relationship between cell number, size, and cyst volume is still constrained for cysts perturbed with either of these drugs, but the parameters of the constraint (specifically the slope) are different from unperturbed cysts. 
We then wondered how a perturbation which does change a constraint influences other constraints - if cysts perturbed with drug $\mathrm{X}$ do not obey the constant-cell-density constraint, must they also not obey the lumen-number-cap constraint? We found that cysts perturbed with givinostat (a histone deacetylase inhibitor), idelalisib (a phosphoinositide 3-kinase delta isoform inhibitor), sumatriptan succinate, and Aurora A Inhibitor I had more lumens in a given cyst volume than unperturbed cysts of any age (Fig. 3F). Thus, cysts perturbed with these drugs do not obey the same lumen-number-cap constraint of unperturbed cysts, instead they obey a constraint with a larger slope. Further, some perturbations (givinostat, idelalisib, and Aurora A Inhibitor I), which changed the lumen-number-cap constraint, did not change the constant-cell-density constraint. That some perturbations change one constraint without changing the other suggests that the set of morphologies available to MDCK cysts is richer than unperturbed cysts would suggest.

Constraints of perturbed cysts do not add together or average out when multiple perturbations are applied

Exposing MDCK cysts to hepatocyte growth factor (HGF) in collagen gels induces cells to send out spindly protrusions (Montesano, Schaller, and Orci 1991; Montesano et al. 1991). These protrusions form the groundwork for a chain of cells to proliferate and ultimately form tubules. We wondered how such a perturbation might change the constraints on cyst morphologies we identified, given that it leads to known, qualitative changes in cyst morphology. We added HGF to MDCK cysts as they grew for nine days (Fig. 4A). We used our imaging and feature quantification approach to characterize the constraints on cysts exposed to HGF. We asked whether our measurements of cyst shape captured the morphology of spindles in HGF-perturbed cysts. We found that one of the primary differences between unperturbed and HGF-perturbed cysts was cyst solidity, a measure of convexity (cysts with more involutions or protrusions have lower solidity than circular or elliptical cysts) (Fig. 4B). Mean cyst solidity decreased from 0.93 for unperturbed cysts to 0.75 for HGF-perturbed cysts. We also found that cysts exposed to HGF were larger, on average, than unperturbed cysts (Fig. 4C).

Given the qualitative difference in morphology of HGF-perturbed cysts, we wondered if HGF-perturbed cysts obeyed the constraints obeyed by unperturbed MDCK cysts. We found that HGF-perturbed cysts did not obey both aspects of the constant-cell-density constraint: while cysts perturbed with HGF had the same number of cells per cyst volume, the cells were larger than those of unperturbed cysts of any age (Fig. 4D-E). 
How do HGF-perturbed cysts have the same number of cells per cyst volume, but larger cells than unperturbed cysts? One possibility was that HGF-perturbed cysts have a smaller proportion of their volume taken up by lumens and a larger proportion of the volume occupied by cells. Interestingly, HGF-perturbed cysts do obey the lumen-number-cap constraint, suggesting that what lumens HGF-perturbed cysts have are smaller in size but similar in number (Fig. 4F). The smaller proportion of volume taken up by the lumens could result from cells being taller or adopting a different configuration. We found that the cells often formed multi-cell layers, which allows for larger cells to occupy the same organoid volume while maintaining the same total number of cells per volume. It also suggests that the strict proportionality between cell number and organoid volume is maintained despite disruptions to cellular configurations and hence cell number may not be controlled by morphology per se.

Given that HGF qualitatively changed some features of MDCK cysts, we wondered what the morphological effects would be upon combining HGF with the previously used perturbations that engendered more quantitative changes. For example, would a perturbation that produces spindly cysts (HGF) and a perturbation that produces smaller cysts yield small, spindly cysts? We perturbed MDCK cysts for nine days with either HGF alone or HGF in combination with lapatinib, orantinib, or with a high starting cell density and HGF (Fig. 4G). We found that cysts exposed to HGF and lapatinib or oratinib had lower solidity, but cysts perturbed with HGF and high cell density did not (Fig. 4H). We found that cysts exposed to HGF, alone or in combination, were also larger, on average, than control cysts (Fig. 4I). Taken together, the morphological changes induced by HGF and another perturbation suggest that the effects of individual perturbations do not necessarily combine additively when administered simultaneously.

We then wondered how the constraints of cysts perturbed with HGF changed when the cysts were exposed to a second drug. One possibility is that doubly-perturbed cysts obeyed a set of constraints that somehow averaged the constraints obeyed by singly-perturbed cysts. Another possibility is that doubly-perturbed cysts obeyed the same set of constraints as only one of the perturbations, suggesting that some drugs may be able to override the effects of others. We first asked if cysts perturbed with HGF and another drug obeyed the same constant-cell-density constraint as cysts perturbed with only HGF (Fig. 4J-K). Cysts perturbed with two perturbations, HGF and lapatinib, oratinib, or high starting cell density, did obey the same constant-cell-density constraint as unperturbed cysts, even though cysts perturbed with HGF alone did not. This difference between the constant-cell-density constraint obeyed by doubly-perturbed cysts and singly-perturbed cysts suggests that some perturbations 
(specifically oratinib, lapatinib, and high starting cell density) are able to cancel out the effects of others (HGF). We also found that only cysts perturbed with both HGF and another perturbation did not obey the same lumen-number-cap constraint as unperturbed cysts, even though cysts perturbed with just one of these perturbations did obey the constraint (Fig. 4L). Cysts perturbed with HGF and lapatinib, oratinib, or high cell density had more lumens for a given cyst volume than unperturbed cyst. In combination, differences between the constraints obeyed by double-perturbed cysts and single-perturbed cysts suggests that the effects of any given perturbation do not appear to simply add together, but rather can combine in unanticipated ways.

\section{Discussion}

Here, we sought to quantify constraints on MDCK cyst morphologies. We found the MDCK cysts obey a number of constraints, and that the majority of their morphological variation can be explained by three dimensions. We also found that some constraints on MDCK cyst morphologies vary with age and perturbations.

It remains unclear what underpins the constraints on cyst (or, more generally, organoid) morphologies. One could imagine any number of potential mechanisms, any one of which might be critical to a constraint by itself or in combination with many others. Such mechanisms may be based upon conventional biochemical signaling (such as signaling between cells to control proliferation), or may involve mechanical sensing of variables such as membrane curvature. While many potential mechanisms may be compatible with our experimental data, perturbations will be required to exclude certain classes of models and establish causality. However, it is also possible that the complexity of the underlying molecular pathways is too great and multi-faceted to ever fully relate to these constraints in an easily understood manner (Mellis and Raj 2015). Nevertheless, these constraints and others like them may constitute an effective "grammar" of organoid morphology that one may be able to build upon irrespective of the molecular details.

We also found that while some perturbations altered cyst parameters within constraints, others changed the nature of the constraint. Knowledge of which types of perturbations lead to which type of effect might aid in the development of an instruction manual for building designer organoids. It may also be possible, with sufficient perturbation, to destroy a constraint, for example to completely decouple cyst volume from the number of cells. With that ability, we might be able to engineer organoids to adopt entirely novel configurations. 
One principal technical challenge in the scaling of approaches such as the one we took here is the extraction of annotations of MDCK cyst structures from microscopy images. Our assumption was that we would need highly accurate annotations to reveal subtle constraints on MDCK cyst morphologies, and those annotations proved difficult to fully automate. Deep learning has produced great advances in automatic image segmentation (Moen et al. 2019), but we found that most methods applied to our data would produce very good results $80 \%$ of the time, and poor results $20 \%$ of the time, which was an insufficient level of accuracy for the conclusions we wanted to draw. While one option is to improve the quality of the algorithms, another is to consider what level of segmentation accuracy is needed for the question at hand. Future work that quantifies what degree of segmentation accuracy is needed for a given question may guide efforts to develop segmentation algorithms.

We focused on MDCK cysts for our proof of concept because of their simplicity, both morphologically and in terms of the number of cell types involved (in this case, just one cell type). Many organoids of interest have several cell types that interact in various ways, presumably to maintain function. It will be interesting in the future to apply this framework to such multi-cell-type organoids to see what constraints are obeyed by the much richer feature sets associated with multi-cell-type interactions. 


\section{Materials and Methods}

\section{MDCK Cyst Culture}

Madin-Darby Canine Kidney-II cells (MilliporeSigma, 00062107-1VL) were maintained by culturing them in $2 \mathrm{D}$ on traditional $10 \mathrm{~cm}$ cell culture-coated dishes (Corning, 353003). The media for both the adherent 2D cells and cysts was MEM media (MediaTech, MT10-010-CM) with 10\% Fetal Bovine Serum (Fisher 16000044) and 1X Penicillin-Streptomycin (Invitrogen 15140122). When the cells were between 30-70\% confluence there were dissociated to make cysts. The cells were briefly washed with 5 $\mathrm{mL}$ of DPBS (Gibco, 14190136). Then, $1 \mathrm{~mL}$ of $0.25 \%$ Trypsin-EDTA (Gibco, 25200056) was added and the plate was incubated at $37^{\circ} \mathrm{C}, 5 \% \mathrm{CO}_{2}$ for $10-15$ minutes. The trypsin was inactivated with $9 \mathrm{~mL}$ of media and the solution was pipetted over the dish three times to ensure all cells detached. The cells were pelleted for 2 minutes at 1000 rpm and then suspended in $500 \mu \mathrm{L}$ to $1 \mathrm{~mL}$ media. The cell concentration was quantified using a BioRad TC20 Automated Cell Counter. The cells were added to ice-cold thawed Matrigel (Corning, 354234) at a concentration of 25,000 cells $/ \mathrm{mL}$. The middle of a well of a Nunc Lab-Tek 8-well Chambered Coverglass (Fisher, 12-565-470) was coated with $5 \mu \mathrm{L}$ of pure Matrigel. Then, $25 \mathrm{uL}$ of the cell-Matrigel suspension was overlaid on top of the coating. The chamber was incubated at $37^{\circ} \mathrm{C}, 5 \% \mathrm{CO}_{2}$ for 30 minutes to solidify the Matrigel. Then, $200 \mathrm{uL}$ of media was added on top of the solidified Matrigel. The cysts were returned to the $37^{\circ} \mathrm{C}, 5 \% \mathrm{CO}_{2}$ incubator and cultured for 3-17 days. The media was replaced every other day.

\section{Imaging}

MDCK cyst fixation and staining was performed at room temperature with two brief washes with 1X PBS (Ambion, AM9624) between each step. When the cysts were ready to be imaged they were fixed in their culture chambers with $1.85 \%$ formaldehyde (MilliporeSigma, F1635-500ML) in PBS for 30 minutes. They were permeabilized with $0.1 \%$ Triton X-100 (MilliporeSigma, T8787-100mL) in PBS overnight. The cysts were then blocked with 5\% Bovine Serum Albumin (MilliporeSigma, A7906-100G) in PBS for 1 hour. The cysts were then incubated with 1:15 488-phalloidin (Invitrogen, A12379) and 1:30 DAPI (Fisher, D3571) in PBS for at least 6 hours before imaging. The cysts were imaged on a Zeiss Laser Scanning 710 Confocal Microscope using a 40X objective (Zeiss, water immersion, 1.1 NA, long working distance, LD C-Apochromat), $405 \mathrm{~nm}$ diode laser (Zeiss), and $488 \mathrm{~nm}$ argon-ion laser (LASOS). Each cyst was imaged from the bottom to a depth clearly beyond the middle point of the cyst. Cysts that were too far from the glass to image that deeply were not imaged. 


\section{Morphological Quantification from Images}

We wrote a custom MATLAB pipeline

(https://github.com/arjunrajlaboratory/organoids2) to measure cyst morphological features from microscopy images by 3D segmenting the boundaries of the whole cyst and each of its lumens and nuclei. To segment the cyst and lumen boundaries our general approach was to guess the boundary on each image slice using the phalloidin image and then manually correct the boundary as needed. To guess the cyst boundary on each slice we set an empty corner of the image as the starting boundary and expanded that boundary outward until the intensity of those pixels was above a user-defined threshold. We applied the same approach to guess the lumen boundaries, except we identified the starting point as the largest object after the slice had been processed with a Laplacian of Gaussian edge detector. We then manually reviewed these 2D boundaries and corrected them as needed (Supp. Fig. 2). Once these 2D boundaries were finalized they were combined to form 3D boundaries. We obtained 3D cyst boundaries by assuming all 2D cyst annotations belonged to the same object. We obtained 3D lumen boundaries by computationally identifying which boundaries touched one another when stacked in 3D. To 2D segment the nuclear boundaries we used cellpose to segment the nuclei on the original image slices. We also sliced the image stack orthogonally from its original slicing, such that moving from slice-to-slice moves left-right across the cyst, rather than up-down. We also used cellpose to segment the nuclei on these orthogonal slices. We then used the orthogonal 2D segmentations to guess which original 2D segmentations were connected to one another. We then manually reviewed these 3D connections and corrected them as needed (Supp. Fig. 3).

Once we had 3D boundaries for the cyst, lumens, and nuclei, we wrote custom analyses to measure morphological features of size, shape, and number for each cyst (Supp. Table 1). For cysts with multiple lumens, we took the mean across all lumens. For cysts with multiple nuclei, we took both the mean and the standard deviation across all nuclei.

\section{PCA and Linear Models}

In order to run PCA we first standardized the units of our features. We took the cube root of all volume features, the square root of all surface area features, and the inverse of the number of lumens. We then z-score normalized each feature. We ran PCA using the prcomp function from the R's stats package 
(https://www.rdocumentation.org/packages/stats/versions/3.6.2). To estimate how much variance we could expect to be explained due to chance, we also ran PCA on randomized data.

We fit linear models to various pairs of morphological features using ggplot2 (https://ggplot2.tidyverse.org/) and R's stats package.

\section{Drug Screen}

We first established MDCK-II cells with stable integration of GFP nuclear and mCherry cell membrane markers. The day before we planned to transfect the cells we plated them so that the cells would be $\sim 80 \%$ confluent at the time of transfection. The cells were cultured in media without antibiotics. The following day, we used Lipofectamine 2000 (Invitrogen, 11668019) to transfect the cells with H2B-GFP plasmid (https://www.addgene.org/11680/). Two days after transfection, we replaced the media with media containing penicillin, streptoymycin, and G418 (Mediatech, MT30-234-CR). We changed the media every other day. One week after transfection we single cell bottlenecked the cells. We then followed the same approach to transfect the cells with mem-mCherry plasmid (https://www.addgene.org/55779/).

To conduct the drug screen, we used Matrix WellMate to plate Matrigel with 35,000 cells $/ \mathrm{mL}$ into 384-well plates. We then centrifuged the plates at $300 \mathrm{rpm}$ for 1 minute to ensure the Matrigel-cell suspension fell to the bottom of the well. We polymerized the Matrigel by placing the plates in a $37^{\circ} \mathrm{C}, 5 \% \mathrm{CO}_{2}$ incubator for 30 minutes. We then added $20 \mathrm{uL}$ of media with $20 \mathrm{mM}$ HEPES and drug using a Perkin Elmer Janus Modular Dispensing Tool. The cysts were cultured for 7 days at $37^{\circ} \mathrm{C}, 5 \% \mathrm{CO}_{2}$.

To image the cysts, we fixed them with 20 uL of $8 \%$ formaldehyde for 30 minuets at room temperature. We washed the plates with PBS and then stained them with 1:2500 Hoescht in PBS overnight. We used a Molecular Device's ImageXpress Micro XLS Widefield High-Content Analysis System to image each plate at 10X. We took 4 images, each at the height determined by the autofocus software, per well.

We then quantified the effect of each drug on cyst size using custom MATLAB scripts. First, we combined the three image channels. We then Gaussian filtered the image and binarized it using Otsu's method. We then obtained the boundary of cysts by obtaining the boundary of all objects in the binary image that were bigger than 50 pixels and smaller than 1500 pixels. We calculated the area of each cyst using MATLAB's regionprops function. We then calculated the average fold change in cyst area for each 
drug by dividing the average cyst area for the drug by the average cyst area for all control cyst from the same plate. We similarly calculate the z-score for each drug.

To identify hits that made the cysts larger, we found drugs in common between the list of top 100 drugs by fold change and the list of top 100 drugs by cyst area. To identify hits that made the cyst smaller, we found drugs in common between the list of both 100 drugs by fold chance and the list of bottom 100 drugs by cyst area.

\section{MDCK Cyst Perturbation Experiments}

MDCK cysts were cultured using the above technique with the following exceptions. For drug perturbations, cysts were cultured in media containing drug throughout their entire growth (Supp. Table 2). Media was replaced every other day. For the high cell density perturbation, the cysts were plated from a cell-Matrigel suspension containing 100,000 cells $/ \mathrm{mL}$. Cysts were fixed and imaged on the 9th day using the protocols described above.

\section{Data and Code Availability}

Our MATLAB pipeline for quantifying morphological features from microscopy images can be found at https://github.com/arjunrajlaboratory/organoids2. We additionally used MATLAB code from https://github.com/arjunrajlaboratory/rajlabimagetools.

All data and remaining code used for these analyses can be found at https://www.dropbox.com/sh/lpfcbq4i2oupxz4/AACKJNSPvLegdxtmR4DPRWRSa?dl $=0$. We used MATLAB to format images for all figures. All other analyses were done in $\mathrm{R}$. We used a selection of color-blind friendly colors for figures 2 - 4 from https://personal.sron.nl/ pault/. 


\section{Acknowledgements}

We thank members of the Raj and Lengner labs for many useful discussions and suggestions. We thank Phil Burnham, Ian Mellis, and Karun Kiani for critical review of the manuscript. We also thank Benjamin Lamarck Emert, Phil Burnham, Yogesh Goyal, Amy Azaria, Karun Kiani, and lan Dardani for help with fixing 3D annotations. We also thank Réka Hollandi from the Horvath lab for assistance in setting up and running their segmentation software, NucleAlzer. We also thank the Penn High Throughput Screening Core (Sara Cherry, David Schultz, and Christopher Rainville) and Penn Cell and Developmental Biology Microscopy Core (Andrea Stout, Jasmine Zhao) for their help and input. LEB acknowledged support from NIH T32 EB009384. AJH acknowledges support from NIH R35 GM133380, NIH R21 GM132831, and the Penn Institute for Translational Medicine and Therapeutics Pilot Grant. ZJG acknowledges support from the Chan Zuckerberg Biohub Investigator Program, NIH U01 CA199315, and the University of California, San Francisco Center for Cellular Construction DBI-1548297. AR acknowledges support from NIH R01 CA238237, NIH Director's Transformative Research Award R01 GM137425, NIH R01 CA232256, NSF CAREER 1350601, NIH P30 CA016520, NIH SPORE P50 CA174523, NIH U01 CA227550, NIH 4DN U01 HL129998, NIH Center for Photogenomics RM1 HG007743, Chan Zuckerberg Initiative Human Cell Atlas 182724, and the Tara Miller Foundation.

\section{Author Contributions}

LEB conceived of the project, performed the experiments, analyzed the data, and wrote the paper. JL, CC, and MCD all provided assistance with manual image annotation. NS and MKC performed some preliminary data analysis. AJH, JDM, and ZJG assisted with crowdsourced image segmentation and also provided valuable intellectual input on the conception of the project. AR conceived of the project, provided guidance in data analysis, and wrote the paper.

\section{Competing Interests}

AR receives royalties related to Stellaris RNA FISH probes. All other authors declare no competing interests. 


\section{References}

Albanese, Alexandre, Justin M. Swaney, Dae Hee Yun, Nicholas B. Evans, Jenna M. Antonucci, Silvia Velasco, Chang Ho Sohn, Paola Arlotta, Lee Gehrke, and Kwanghun Chung. 2020. "Multiscale 3D Phenotyping of Human Cerebral Organoids." Scientific Reports 10 (1): 21487.

Cui, Min-Long, Lucy Copsey, Amelia A. Green, J. Andrew Bangham, and Enrico Coen. 2010. "Quantitative Control of Organ Shape by Combinatorial Gene Activity." PLoS Biology 8 (11): e1000538.

Garreta, Elena, Roger D. Kamm, Susana M. Chuva de Sousa Lopes, Madeline A. Lancaster, Ron Weiss, Xavier Trepat, Insoo Hyun, and Nuria Montserrat. 2020. "Rethinking Organoid Technology through Bioengineering." Nature Materials, November. https://doi.org/10.1038/s41563-020-00804-4.

Gjorevski, Nikolce, Norman Sachs, Andrea Manfrin, Sonja Giger, Maiia E. Bragina,

Paloma Ordóñez-Morán, Hans Clevers, and Matthias P. Lutolf. 2016. "Designer Matrices for Intestinal Stem Cell and Organoid Culture." Nature 539 (7630): 560-64.

Gracz, Adam D., Ian A. Williamson, Kyle C. Roche, Michael J. Johnston, Fengchao Wang, Yuli Wang, Peter J. Attayek, et al. 2015. "A High-Throughput Platform for Stem Cell Niche Co-Cultures and Downstream Gene Expression Analysis." Nature Cell Biology 17 (3): 340-49.

Kassis, Timothy, Victor Hernandez-Gordillo, Ronit Langer, and Linda G. Griffith. 2019. "OrgaQuant: Human Intestinal Organoid Localization and Quantification Using Deep Convolutional Neural Networks." Scientific Reports 9 (1): 1-7.

Kim, Jihoon, Bon-Kyoung Koo, and Juergen A. Knoblich. 2020. "Human Organoids:

Model Systems for Human Biology and Medicine." Nature Reviews. Molecular Cell Biology 21 (10): 571-84.

Koo, Bonsang, Baekgyu Choi, Hoewon Park, and Ki-Jun Yoon. 2019. "Past, Present, and Future of Brain Organoid Technology." Molecules and Cells 42 (9): 617-27.

Lukonin, Ilya, Denise Serra, Ludivine Challet Meylan, Katrin Volkmann, Janine Baaten, Rui Zhao, Shelly Meeusen, et al. 2020. "Phenotypic Landscape of Intestinal Organoid Regeneration." Nature 586 (7828): 275-80.

Mellis, Ian A., and Arjun Raj. 2015. "Half Dozen of One, Six Billion of the Other: What Can Small- and Large-Scale Molecular Systems Biology Learn from One Another?" Genome Research 25 (10): 1466-72.

Moen, Erick, Dylan Bannon, Takamasa Kudo, William Graf, Markus Covert, and David Van Valen. 2019. "Deep Learning for Cellular Image Analysis.” Nature Methods 16 (12): 1233-46.

Montesano, R., K. Matsumoto, T. Nakamura, and L. Orci. 1991. "Identification of a 
Fibroblast-Derived Epithelial Morphogen as Hepatocyte Growth Factor." Cell 67

(5): 901-8.

Montesano, R., G. Schaller, and L. Orci. 1991. "Induction of Epithelial Tubular

Morphogenesis in Vitro by Fibroblast-Derived Soluble Factors." Cell 66 (4): 697-711.

Peng, Juan, Aline Awad, Sokhavuth Sar, Ola Hamze Komaiha, Romina Moyano, Amel

Rayal, Didier Samuel, et al. 2015. "Phosphoinositide 3-Kinase p110ठ Promotes

Lumen Formation through the Enhancement of Apico-Basal Polarity and Basal

Membrane Organization." Nature Communications 6 (January): 5937.

Phipson, Belinda, Pei X. Er, Alexander N. Combes, Thomas A. Forbes, Sara E.

Howden, Luke Zappia, Hsan-Jan Yen, et al. 2019. "Evaluation of Variability in

Human Kidney Organoids." Nature Methods 16 (1): 79-87.

Piccinini, Filippo, Tamas Balassa, Antonella Carbonaro, Akos Diosdi, Timea Toth, Nikita

Moshkov, Ervin A. Tasnadi, and Peter Horvath. 2020. "Software Tools for 3D Nuclei

Segmentation and Quantitative Analysis in Multicellular Aggregates."

Computational and Structural Biotechnology Journal 18 (June): 1287-1300.

Sidhaye, Jaydeep, and Jürgen A. Knoblich. 2020. "Brain Organoids: An Ensemble of

Bioassays to Investigate Human Neurodevelopment and Disease." Cell Death and

Differentiation, June. https://doi.org/10.1038/s41418-020-0566-4.

Stephens, Greg J., Bethany Johnson-Kerner, William Bialek, and William S. Ryu. 2008.

"Dimensionality and Dynamics in the Behavior of C. Elegans." PLoS Computational Biology 4 (4): e1000028.

Stringer, Carsen, Tim Wang, Michalis Michaelos, and Marius Pachitariu. 2020.

"Cellpose: A Generalist Algorithm for Cellular Segmentation." Nature Methods,

December. https://doi.org/10.1038/s41592-020-01018-x.

Volpato, Viola, James Smith, Cynthia Sandor, Janina S. Ried, Anna Baud, Adam

Handel, Sarah E. Newey, et al. 2018. "Reproducibility of Molecular Phenotypes

after Long-Term Differentiation to Human iPSC-Derived Neurons: A Multi-Site

Omics Study." Stem Cell Reports 11 (4): 897-911.

Yin, Xiaolei, Henner F. Farin, Johan H. van Es, Hans Clevers, Robert Langer, and Jeffrey M. Karp. 2014. "Niche-Independent High-Purity Cultures of Lgr5+ Intestinal Stem Cells and Their Progeny." Nature Methods 11 (1): 106-12. 
bioRxiv preprint doi: https://doi.org/10.1101/2021.01.08.425947; this version posted January 8, 2021. The copyright holder for this preprint (which was not certified by peer review) is the author/funder, who has granted bioRxiv a license to display the preprint in perpetuity. It is made available under aCC-BY 4.0 International license.

\section{Figure 1}

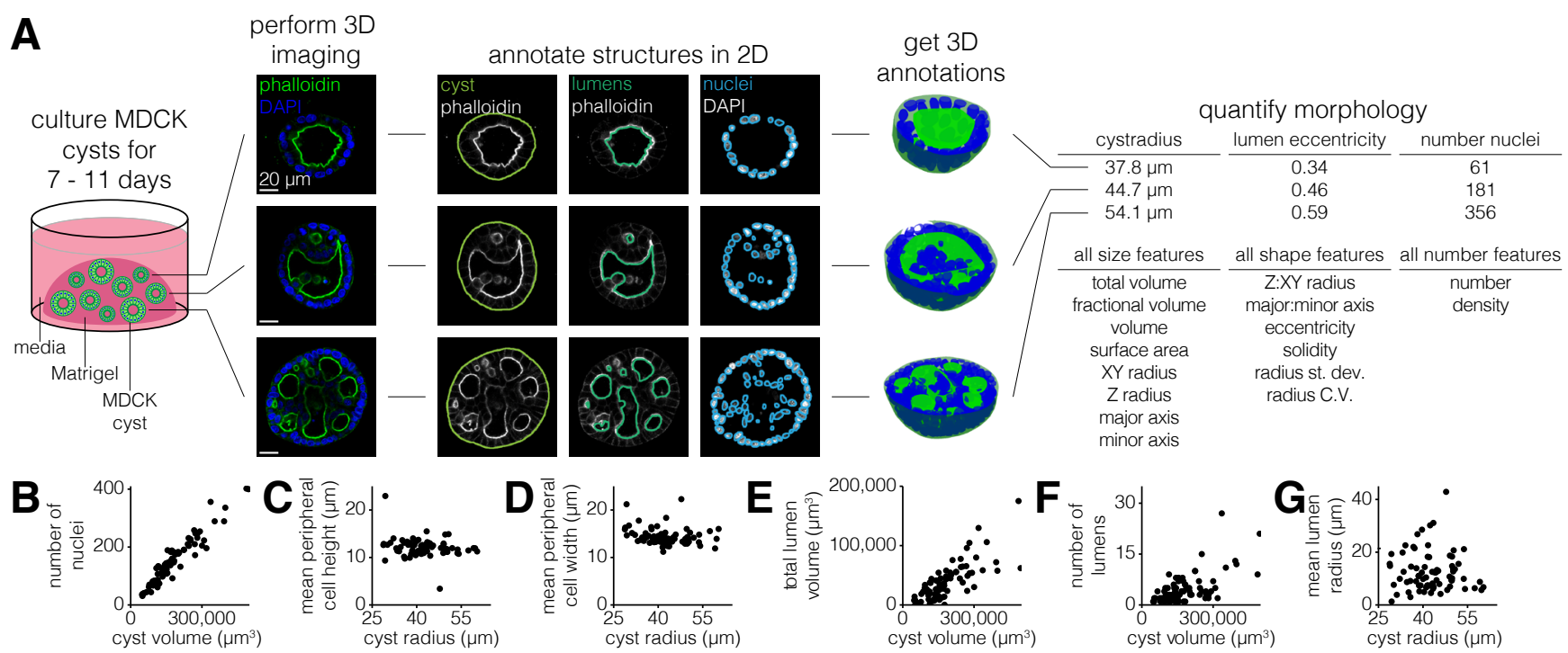

H
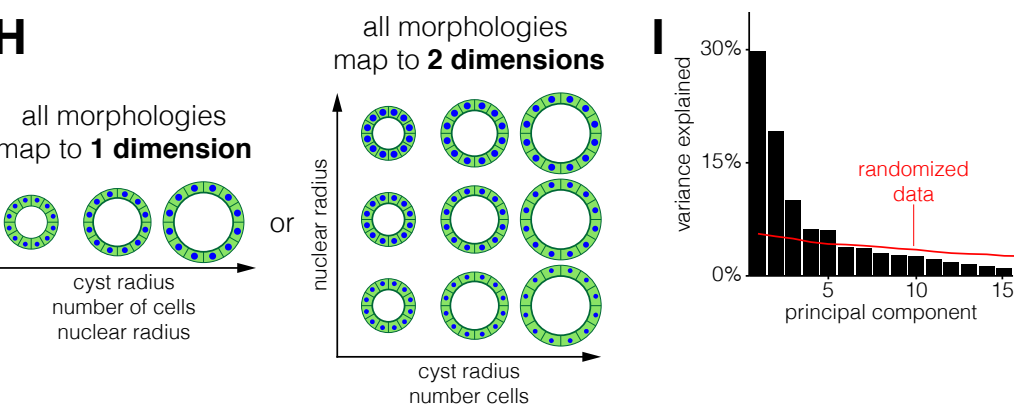

$\mathbf{J}$
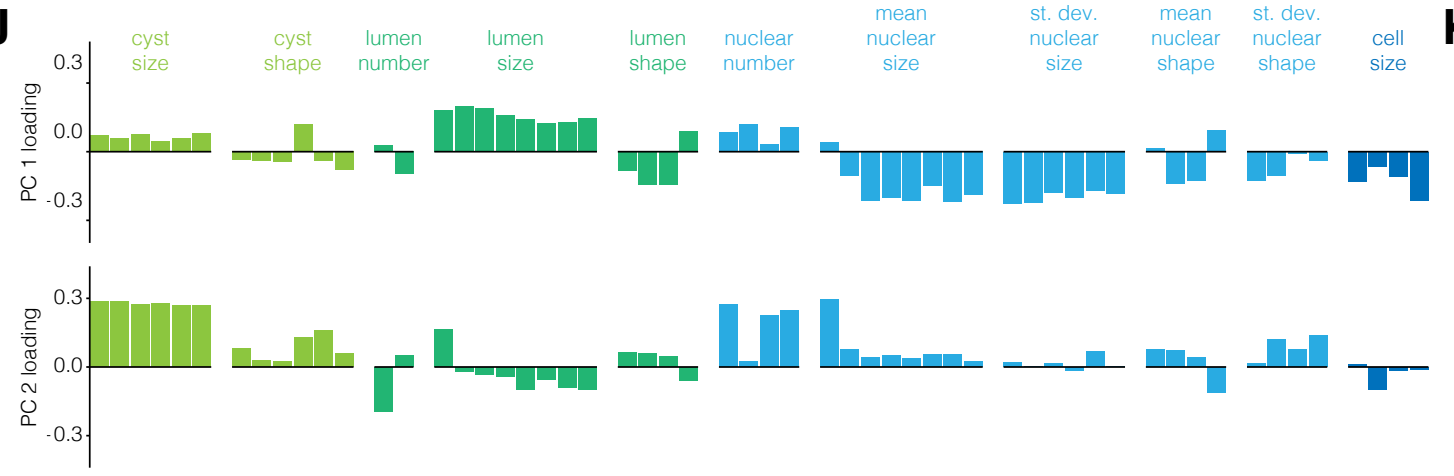

all morphologies map to 2 dimensions
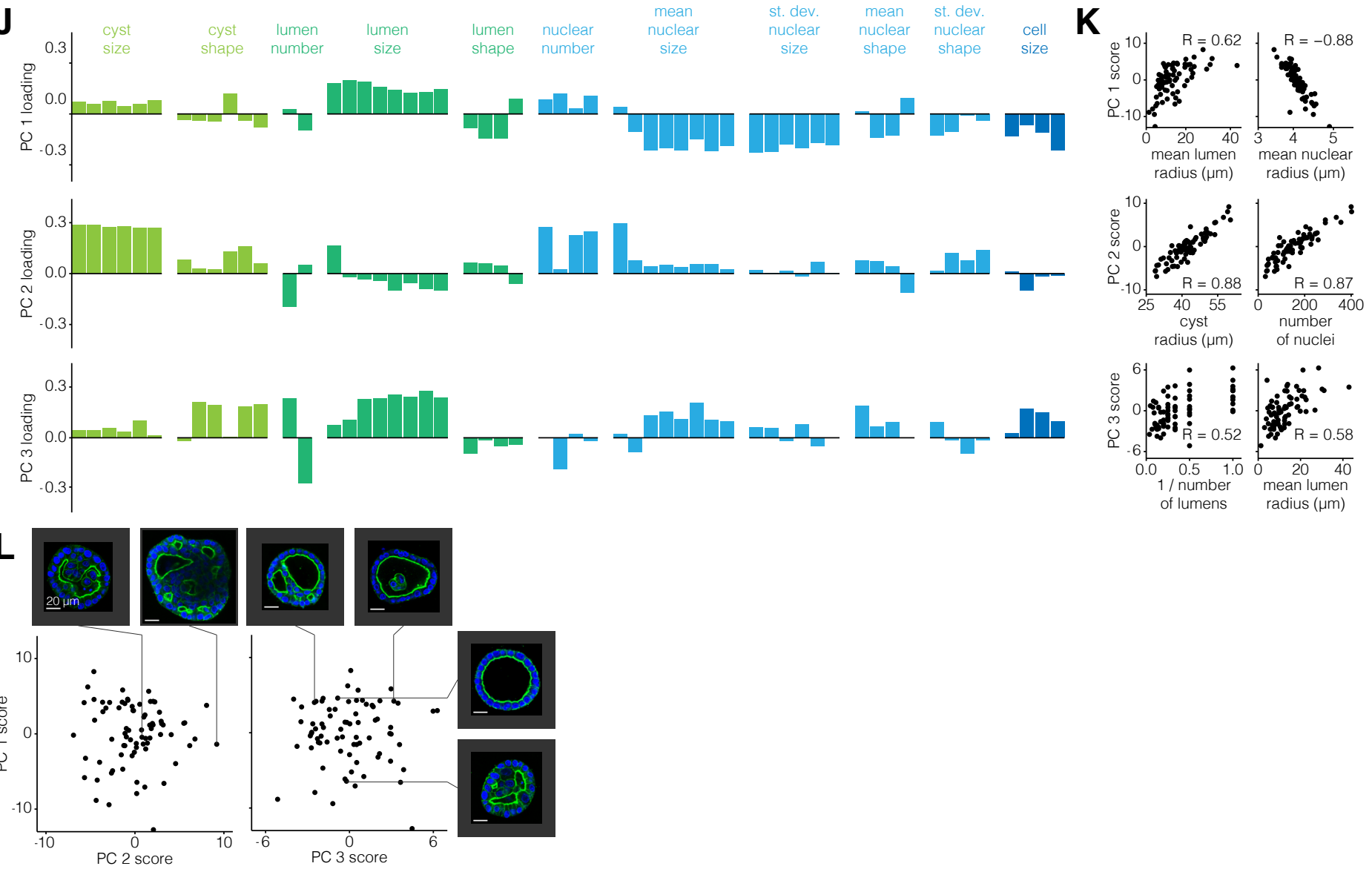
Figure 1: MDCK cyst morphologies span a limited number of dimensions.

A. Schematic of experiments to quantify MDCK cyst morphological features. Briefly, we culture cysts for a variable number of days, perform 3D imaging of nuclei and cell boundaries for at least half of the cyst, annotate the boundaries of the cyst and each nucleus and lumen, and measure morphological features on the 3D annotations.

B-G. Comparison of two morphological features for a time-window of 7-11 day old MDCK cysts.

H. Example schematic of MDCK cyst morphologies that are captured by 1 dimension or 2 dimensions.

I. Variance explained by each principal component. The red line indicates how much variance is explained when the data is randomized before PCA (see methods for details).

J. Loading of each feature on principal components one through three. Each feature is color-coded by what structure (cyst, lumen, nucleus, or cell) it describes.

K. Correlation between principal component score and raw morphological features for features which highly contribute to that principal component.

L. Principal component scores for the first three principal components. Each pair of example cysts were chosen because they have high vs low score for one principal component, and similar scores for the other two principal components. 
bioRxiv preprint doi: https://doi.org/10.1101/2021.01.08.425947; this version posted January 8, 2021. The copyright holder for this preprint (which was not certified by peer review) is the author/funder, who has granted bioRxiv a license to display the preprint in perpetuity. It is made available under aCC-BY 4.0 International license.

Figure 2

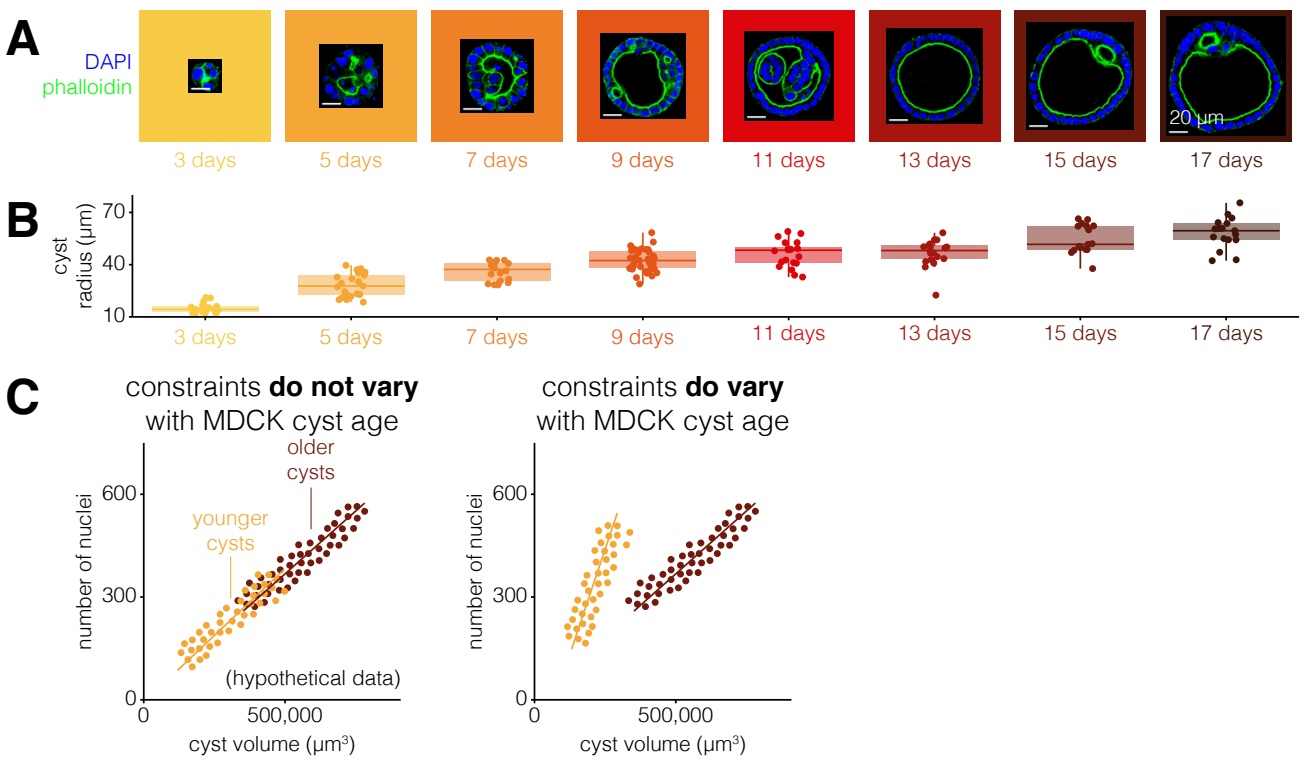

D constant-cell-density constraint
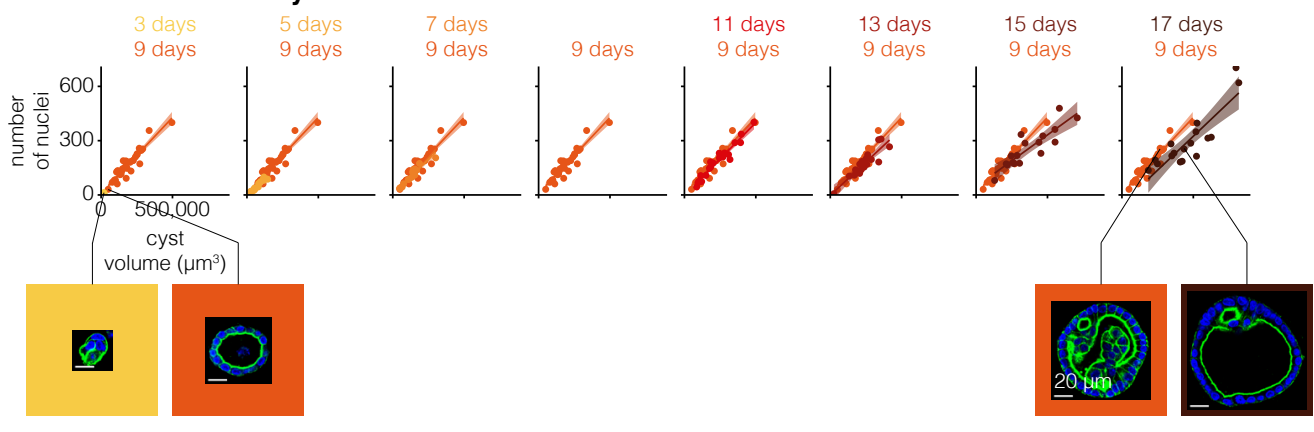

\section{E constant-cell-density constraint}

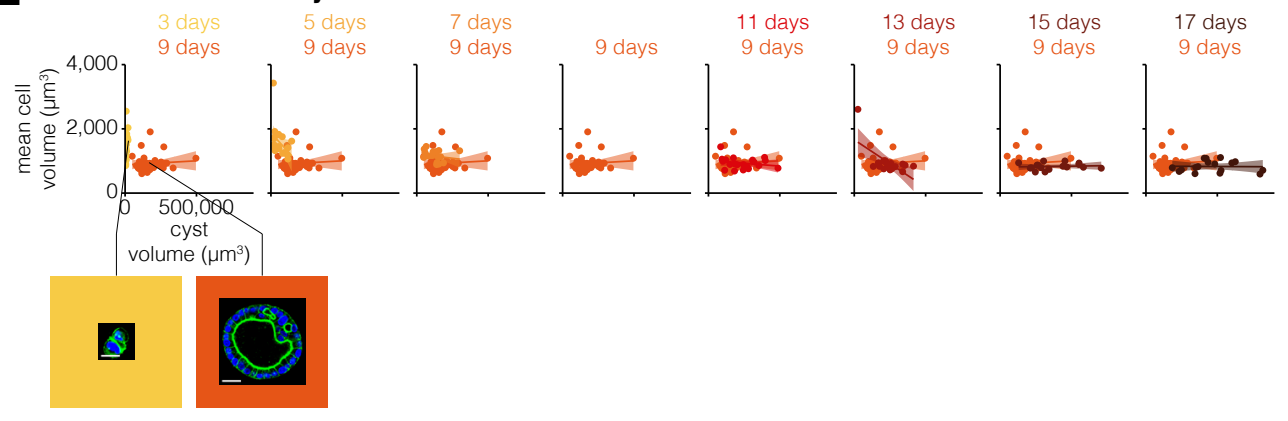

\section{F lumen-number-cap constraint}

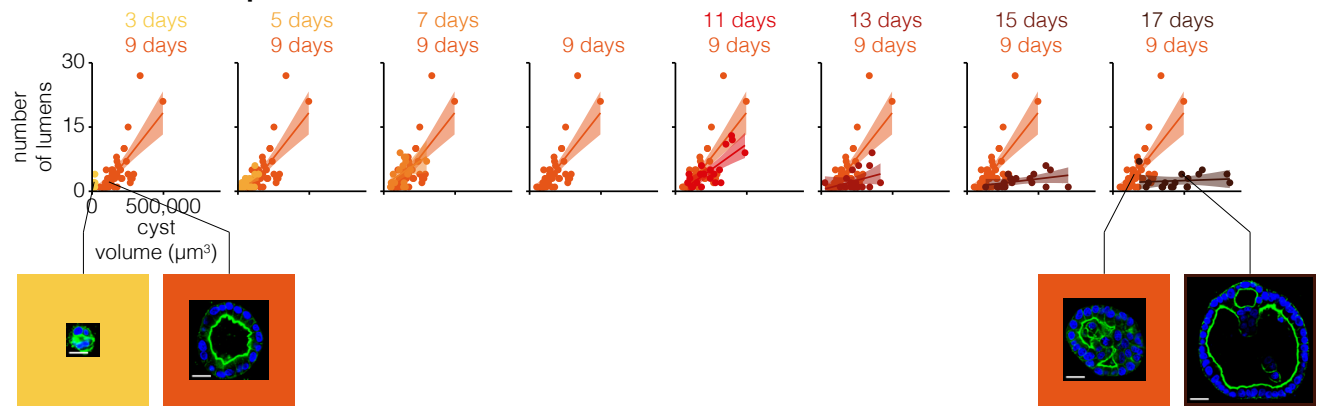


Figure 2: Constraints on MDCK cyst morphologies vary with age.

A. Example MDCK cysts cultured for 3-17 days.

B. Quantification of cyst radius for MDCK cysts of different ages.

C. Example of a constraint that does or does not vary with MDCK cyst age for hypothetical data.

D. Number of nuclei versus cyst volume for MDCK cysts of each age. Each age is represented by one color, and 9 day old MDCK cysts are repeated on each graph for reference. The line represents the line of best fit and the shaded area represents the $95 \%$ confidence interval. Example MDCK cysts with approximately the same number of nuclei but different volumes.

E. Mean cell volume versus cyst volume for MDCK cysts of each age. Each age is represented by one color, and 9 day old MDCK cysts are repeated on each graph for reference. The line represents the line of best fit and the shaded area represents the $95 \%$ confidence interval. Example MDCK cysts with approximately the same volume but different mean cell volumes.

F. Number of lumens versus cyst volume for MDCK cysts of each age. Each age is represented by one color, and 9 day old MDCK cysts are repeated on each graph for reference. The line represents the line of best fit and the shaded area represents the $95 \%$ confidence interval. Example MDCK cysts with approximately the same number of lumens but different cyst volumes. 
bioRxiv preprint doi: https://doi.org/10.1101/2021.01.08.425947; this version posted January 8, 2021. The copyright holder for this preprint (which was not certified by peer review) is the author/funder, who has granted bioRxiv a license to display the preprint in perpetuity. It is made available under aCC-BY 4.0 International license.

\section{Figure 3}

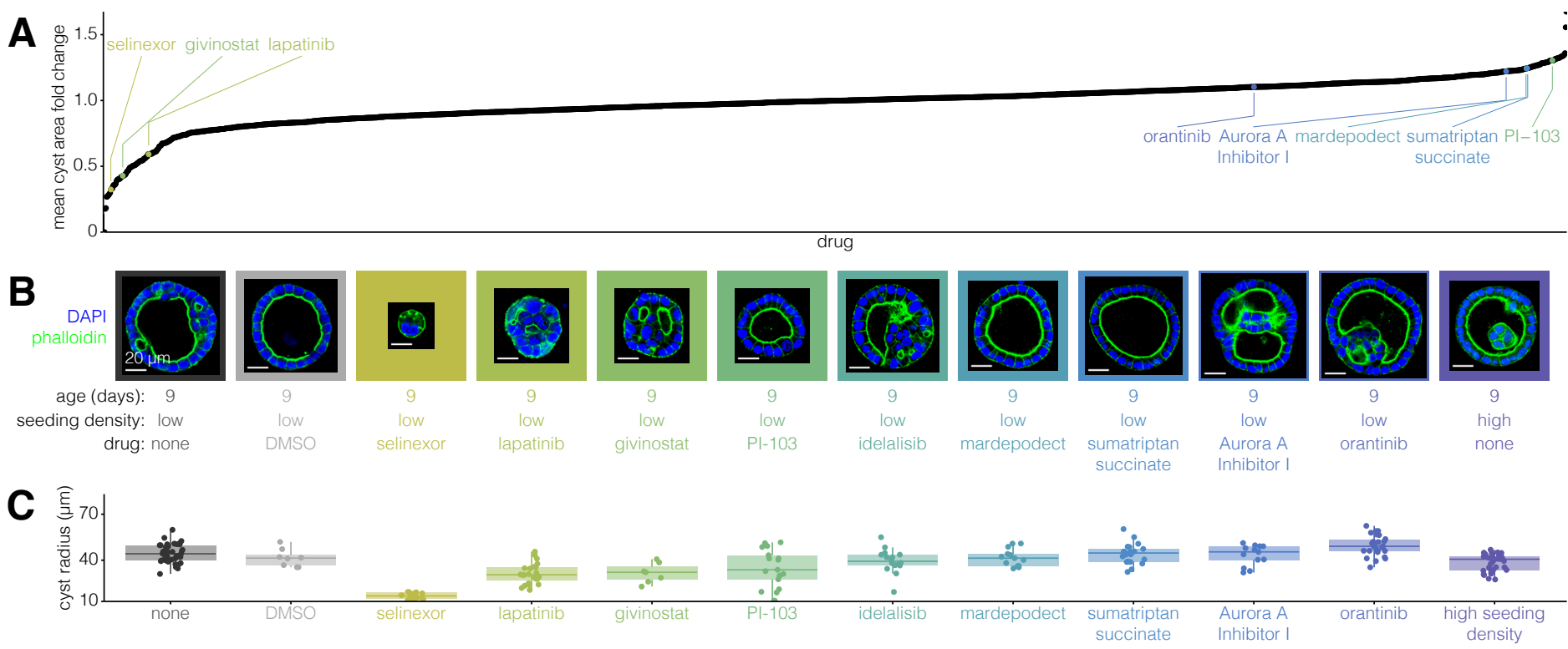

\section{D constant-cell-density constraint}
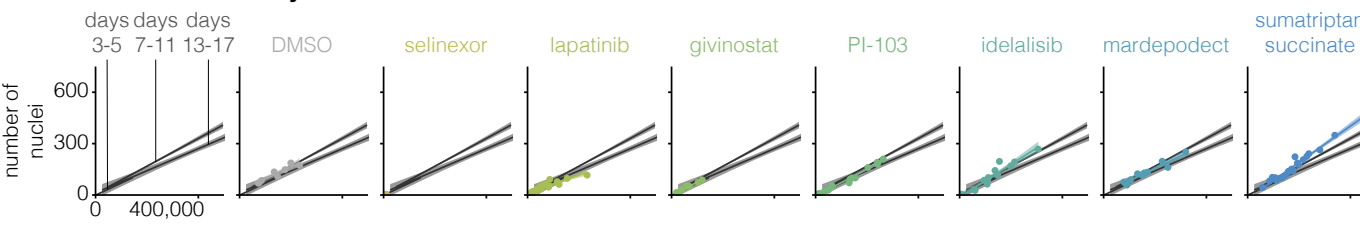

Aurora A

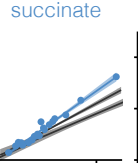

Inhibitor

cyst volume $\left(\mu \mathrm{m}^{3}\right)$

\section{E constant-cell-density constraint}
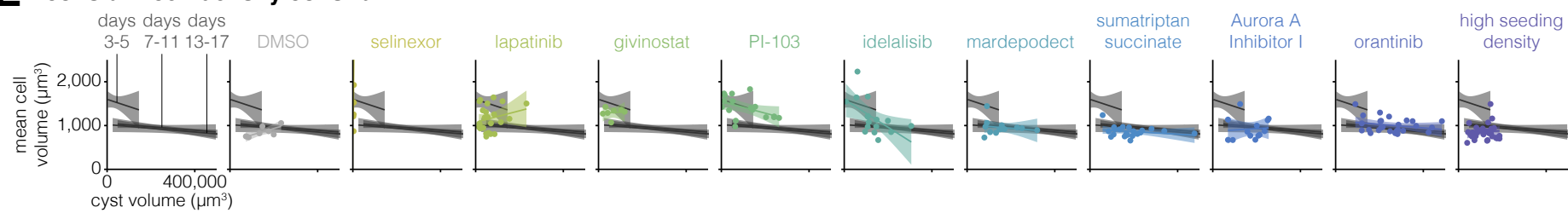

F lumen-number-cap constraint
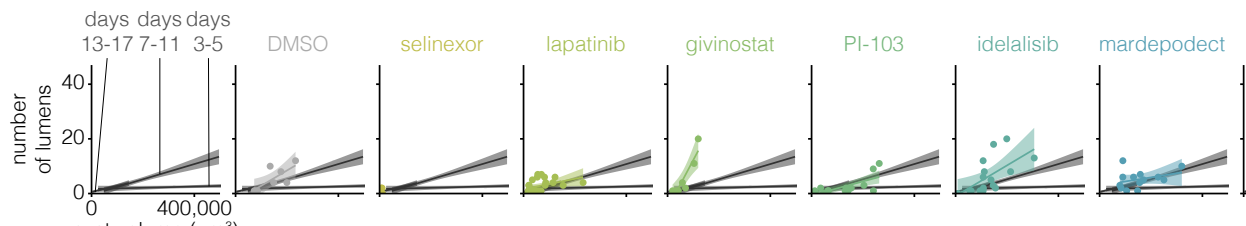

sumatriptan

Aurora A

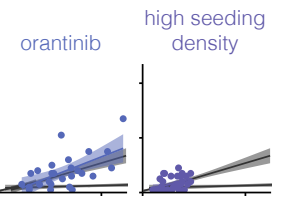
cyst volume $\left(\mu \mathrm{m}^{3}\right)$ 
Figure 3: Drug and environmental perturbations can change constraint parameters but do not break them.

A. Fold change in cyst area versus each drug from the screen. Annotated drugs are those used in further experiments.

B. Example MDCK cysts for each perturbation. The seeding cell density, low $(25,000$ cells $/ \mathrm{mL}$ ) or high $(100,000$ cells $/ \mathrm{mL})$, and the drug added to the culture media are indicated below the image. The MDCK cyst shown is one with approximately average radius for that perturbation.

C. Quantification of cyst radius for MDCK cysts exposed to different perturbations.

D. Number of nuclei versus cyst volume for MDCK cysts exposed to different perturbations. Each perturbation is represented by one color. The line represents the line of best fit and the shaded area represents the $95 \%$ confidence interval. The line of best fit and $95 \%$ confidence interval for three groups of unperturbed MDCK cysts (3-5 days, 7-11 days, and 13-17 days) are shown in gray for reference.

E. Mean cell volume versus cyst volume for MDCK cysts exposed to different perturbations. Each perturbation is represented by one color. The line represents the line of best fit and the shaded area represents the $95 \%$ confidence interval. The line of best fit and $95 \%$ confidence interval for three groups of unperturbed MDCK cysts (3-5 days, 7-11 days, and 13-17 days) are shown in gray for reference.

F. Number of lumens versus cyst volume for MDCK cysts exposed to different perturbations. Each perturbation is represented by one color. The line represents the line of best fit and the shaded area represents the $95 \%$ confidence interval. The line of best fit and $95 \%$ confidence interval for three groups of unperturbed MDCK cysts (3-5 days, 7-11 days, and 13-17 days) are shown in gray for reference. 
bioRxiv preprint doi: https://doi.org/10.1101/2021.01.08.425947; this version posted January 8, 2021. The copyright holder for this preprint (which was not certified by peer review) is the author/funder, who has granted bioRxiv a license to display the preprint in perpetuity. It is made available under aCC-BY 4.0 International license.

Figure 4

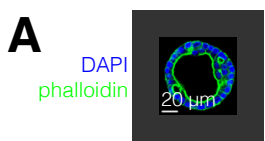

age (days): 9

seeding density: low

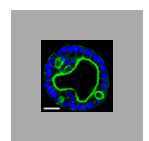

9

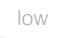

BBS, 5\% BSA

B

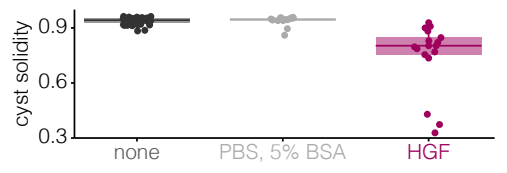

C

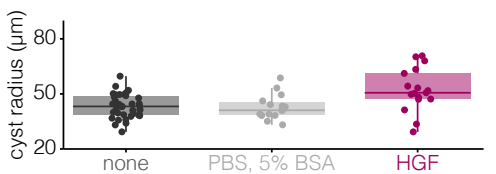

D constant-cell-density constraint

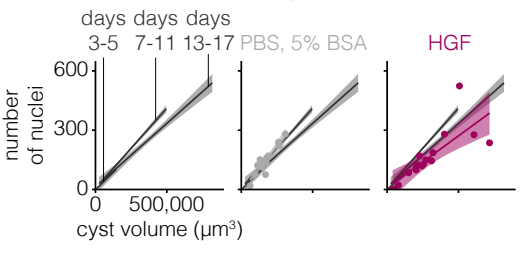

E constant-cell-density constraint

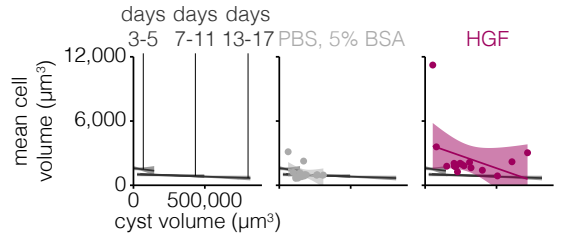

F lumen-number-cap constraint

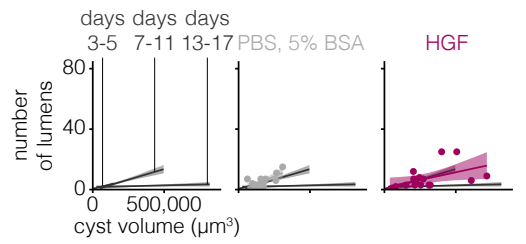

G

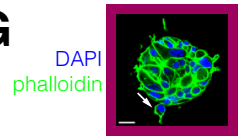

age (days): 9 seeding density: low drug: HGF

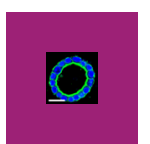

9

low
lapatinib

H

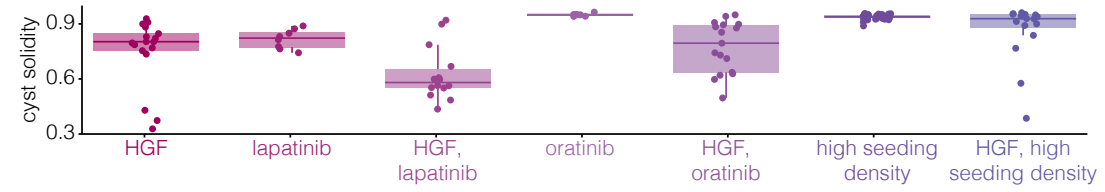

I

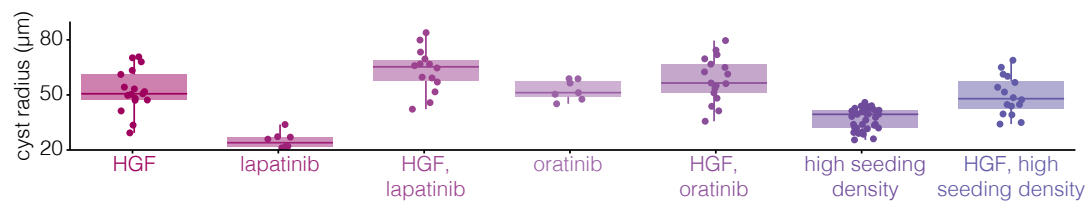

J constant-cell-density constraint

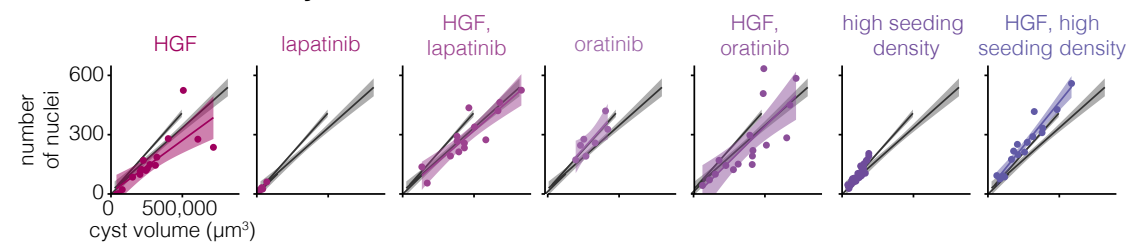

K constant-cell-density constraint

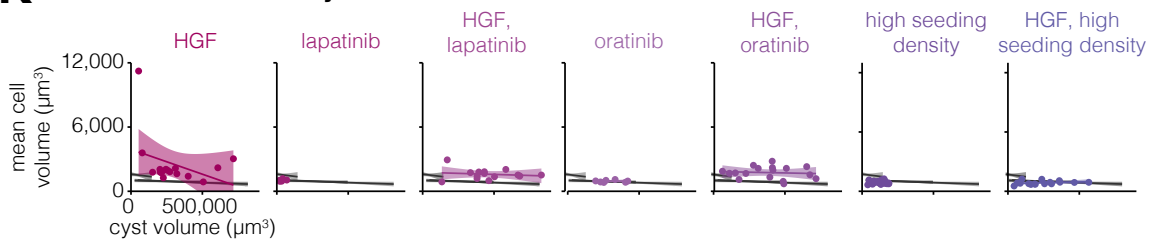

L lumen-number-cap constraint

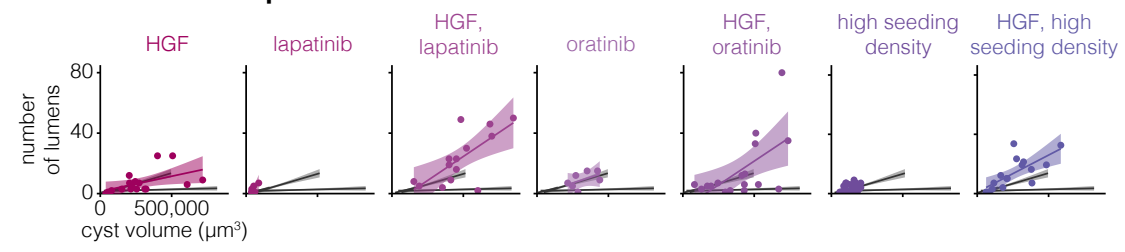


Figure 4: Constraints of perturbed cysts do not add together or average out when multiple perturbations are applied.

A, G. Example MDCK cysts cultured for each perturbation. The seeding cell density, low $(25,000$ cells $/ \mathrm{mL})$ or high $(100,000$ cells $/ \mathrm{mL})$, and the drug added to the culture media are indicated below the image. The MDCK cyst shown is one with approximately average radius for that perturbation. White arrows indicate spindles.

B, H. Quantification of cyst solidity for MDCK cysts exposed to different perturbations. C, I. Quantification of cyst volume for MDCK cysts exposed to different perturbations. D, J. Number of nuclei versus cyst volume for MDCK cysts exposed to different perturbations. Each perturbation is represented by one color. The line represents the line of best fit and the shaded area represents the $95 \%$ confidence interval. The line of best fit and 95\% confidence interval for three groups of unperturbed MDCK cysts (3-5 days, 7-11 days, and 13-17 days) are shown in gray for reference.

E, K. Mean cell volume versus cyst volume for MDCK cysts exposed to different perturbations. Each perturbation is represented by one color. The line represents the line of best fit and the shaded area represents the 95\% confidence interval. The line of best fit and 95\% confidence interval for three groups of unperturbed MDCK cysts (3-5 days, 7-11 days, and 13-17 days) are shown in gray for reference.

F, L. Number of lumens versus cyst volume for MDCK cysts exposed to different perturbations. Each perturbation is represented by one color. The line represents the line of best fit and the shaded area represents the $95 \%$ confidence interval. The line of best fit and 95\% confidence interval for three groups of unperturbed MDCK cysts (3-5 days, 7-11 days, and 13-17 days) are shown in gray for reference. 
bioRxiv preprint dol: https://doi.org/10.1101/2021.01.08.425947; this version posted January $8,2021$. The copyright holder for this preprint

(which was not certified by peer review) is the author/funder, who has granted bioRxiv a license to display the preprint in perpetuity. It is made

available under aCC-BY 4.0 International license.

Supplemental Figure 1

A
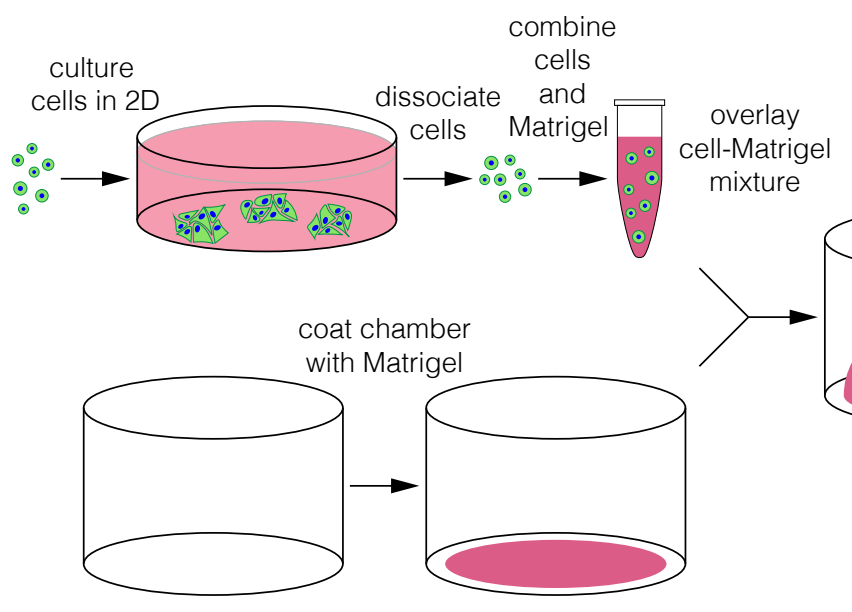


\section{Supplemental Figure 1: Schematic for MDCK cyst culture technique.}

A. MDCK cells are maintained in two-dimensional culture. When the cells are sufficiently confluent, they are dissociated into a single cell suspension. Cells are added to liquid Matrigel and the cell-Matrigel mixture is plated into a cell culture chamber already coated with pure Matrigel. After the Matrigel has polymerized, media can be added and the cysts can be cultured for at least 17 days. See methods for more information. 
bioRxiv preprint doi: https://doi.org/10.1101/2021.01.08.425947; this version posted January 8, 2021. The copyright holder for this preprint (which was not certified by peer review) is the author/funder, who has granted bioRxiv a license to display the preprint in perpetuity. It is made available under aCC-BY 4.0 International license.

\section{Supplemental Figure 2}

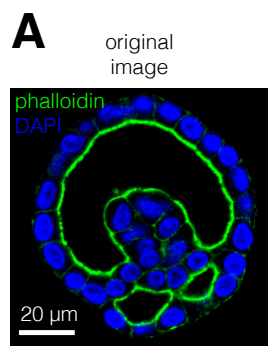

B $\underset{\substack{\text { candidate } \\ \text { cyst }}}{\text { C }}$

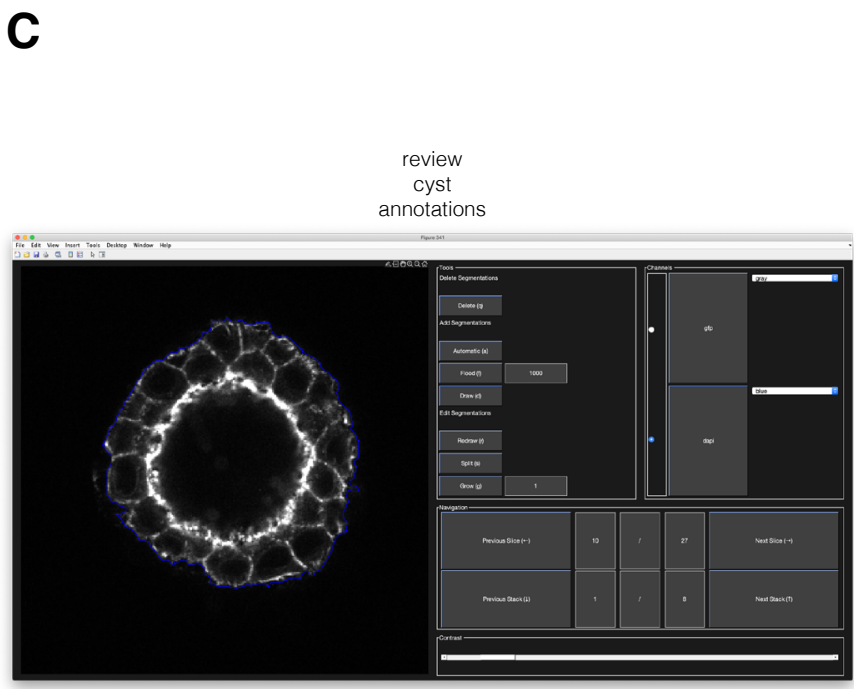

D corrected
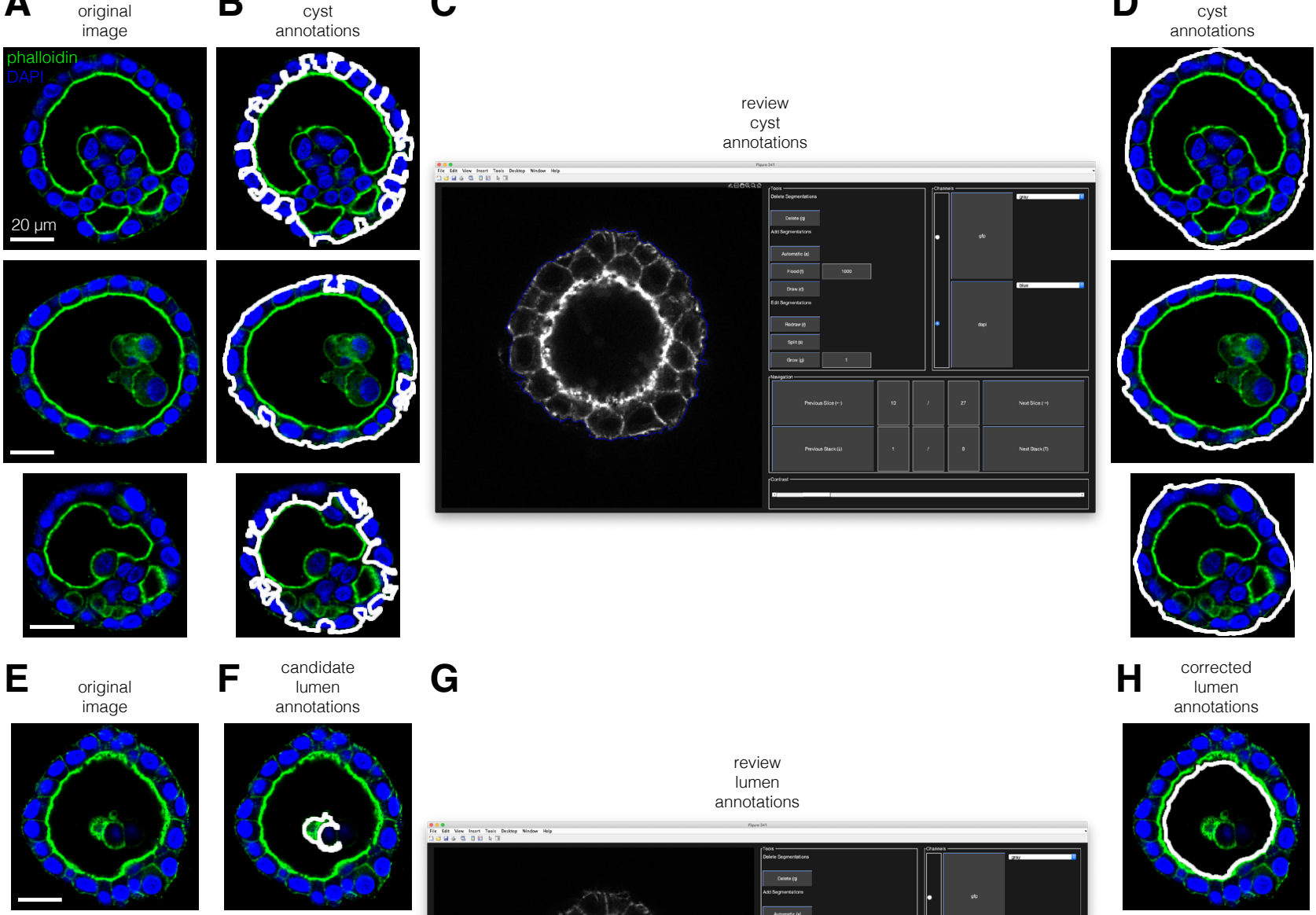

F candidate annotations

G
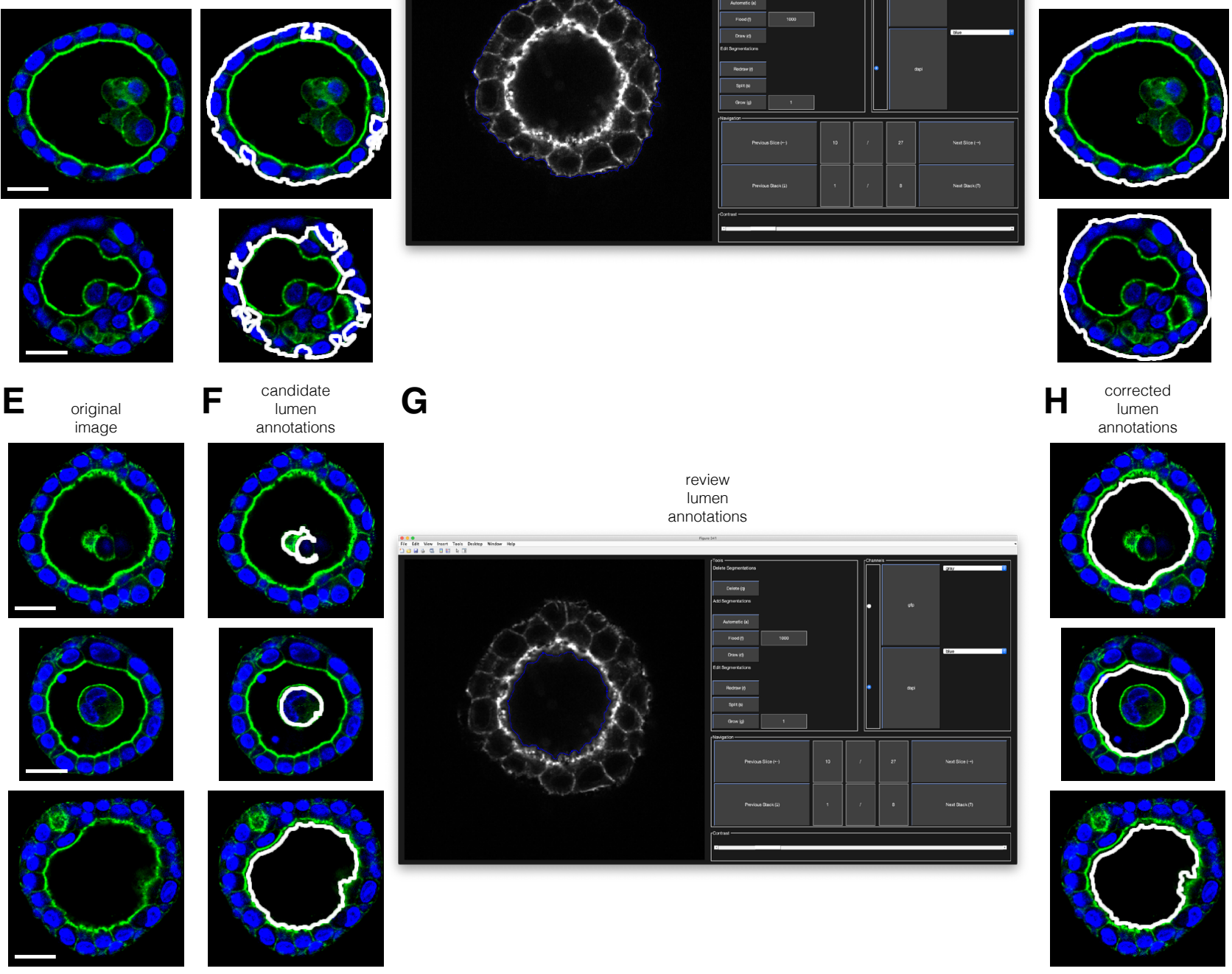

\section{H corrected annotations}
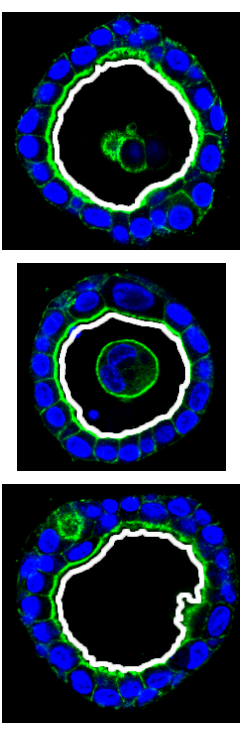


\section{Supplemental Figure 2: Manually correcting 2D cyst and lumen annotations.}
A. Example images of MDCK cysts.
B. Example candidate annotations for the cyst boundary.
C. Our user interface for viewing and correcting 2D annotations.
D. Example annotations for the cyst boundary after correction.
E. Example images of MDCK cysts.
F. Example candidate annotations for the lumen boundaries.
G. Our user interface for viewing and correcting 2D annotations.
H. Example annotations for the lumen boundaries after correction. 
bioRxiv preprint doi: https://doi.org/10.1101/2021.01.08.425947; this version posted January 8, 2021. The copyright holder for this preprint (which was not certified by peer review) is the author/funder, who has granted bioRxiv a license to display the preprint in perpetuity. It is made available under aCC-BY 4.0 International license.

\section{Supplemental Figure 3}

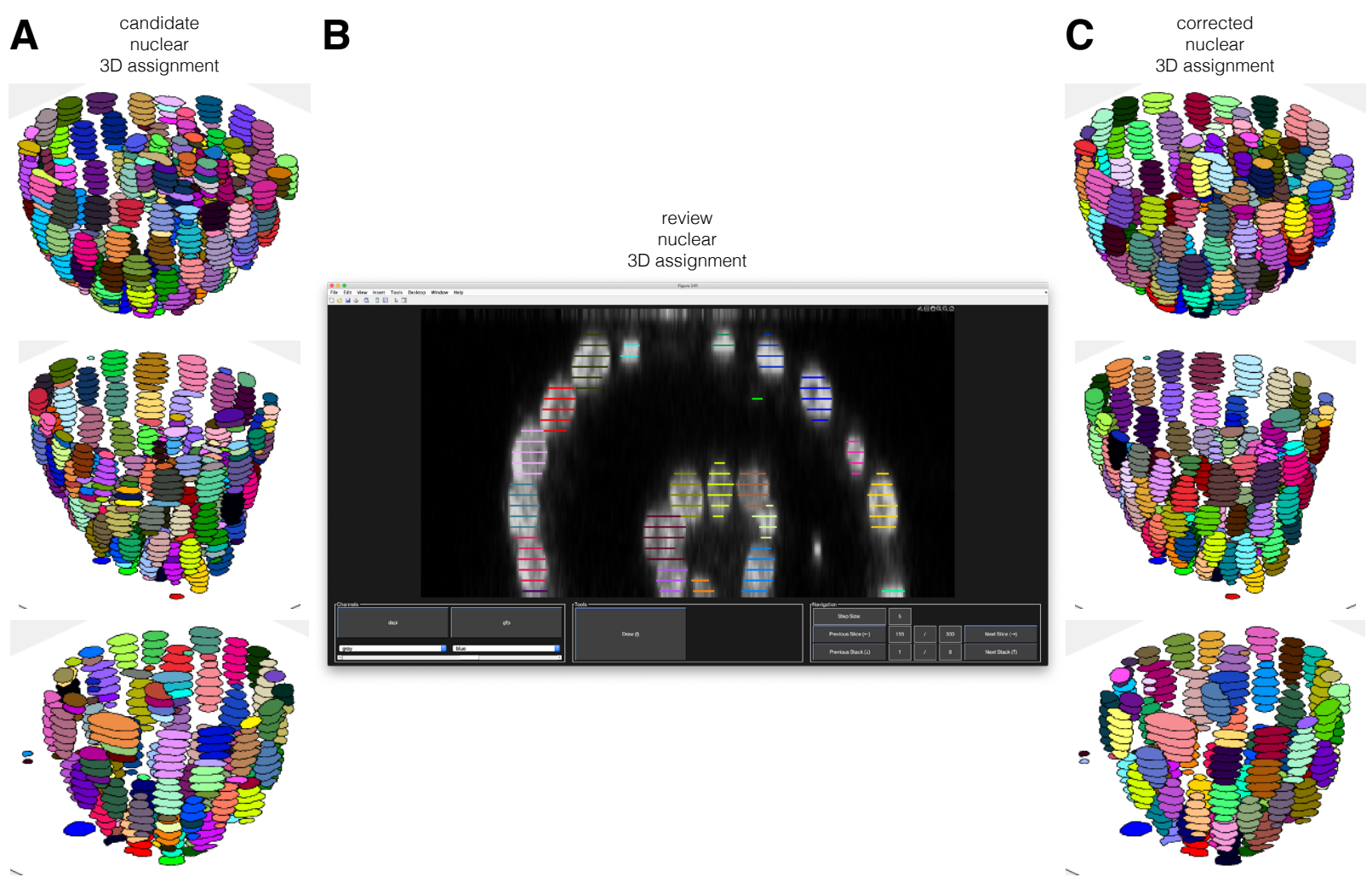


bioRxiv preprint doi: https://doi.org/10.1101/2021.01.08.425947; this version posted January 8, 2021. The copyright holder for this preprint

(which was not certified by peer review) is the author/funder, who has granted bioRxiv a license to display the preprint in perpetuity. It is made available under aCC-BY 4.0 International license.

Supplemental Figure 3: Manually correcting 3D nuclear annotations.

A. Example candidate nuclear annotations, color-coded by which 3D object they belong to.

B. Our user interface for viewing and correcting 3D nuclear annotations.

C. Example nuclear annotations after they have been manually corrected. 
bioRxiv preprint doi: https://doi.org/10.1101/2021.01.08.425947; this version posted January 8, 2021. The copyright holder for this preprint (which was not certified by peer review) is the author/funder, who has granted bioRxiv a license to display the preprint in perpetuity. It is made available under aCC-BY 4.0 International license.

\section{Supplemental Figure 4}

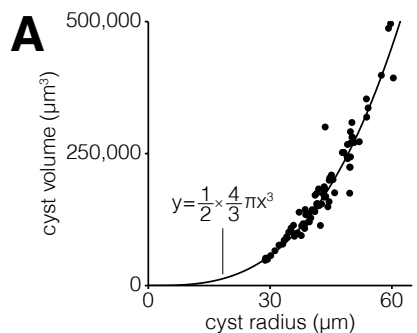


bioRxiv preprint doi: https://doi.org/10.1101/2021.01.08.425947; this version posted January 8, 2021. The copyright holder for this preprint

(which was not certified by peer review) is the author/funder, who has granted bioRxiv a license to display the preprint in perpetuity. It is made available under aCC-BY 4.0 International license.

Supplemental Figure 4: Cyst volume scales with cyst radius to the third.

A. Cyst volume versus cyst radius for 7-11 day old MDCK cysts. Reference line indicates the relationship between radius and volume of half a sphere. 
bioRxiv preprint doi: https://doi.org/10.1101/2021.01.08.425947; this version posted January 8, 2021. The copyright holder for this preprint (which was not certified by peer review) is the author/funder, who has granted bioRxiv a license to display the preprint in perpetuity. It is made available under aCC-BY 4.0 International license.

\section{Supplemental Figure 5}
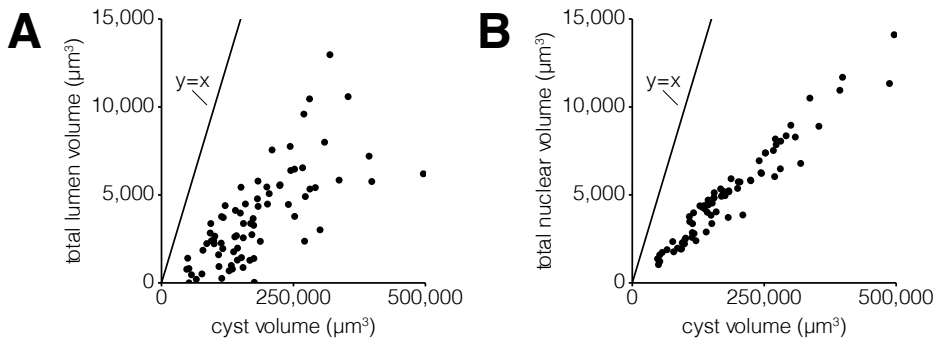


\section{Supplemental Figure 5: Total lumen and nuclear volumes are less than cyst volume.}

A. Total lumen volume versus cyst volume for 7-11 day old MDCK cysts. Reference line indicates $y=x$.

B. Total nuclear volume versus cyst volume for 7-11 day old MDCK cysts. Reference line indicates $y=x$. 
bioRxiv preprint doi: https://doi.org/10.1101/2021.01.08.425947; this version posted January 8, 2021. The copyright holder for this preprint (which was not certified by peer review) is the author/funder, who has granted bioRxiv a license to display the preprint in perpetuity. It is made available under aCC-BY 4.0 International license.

\section{Supplemental Figure 6}

A
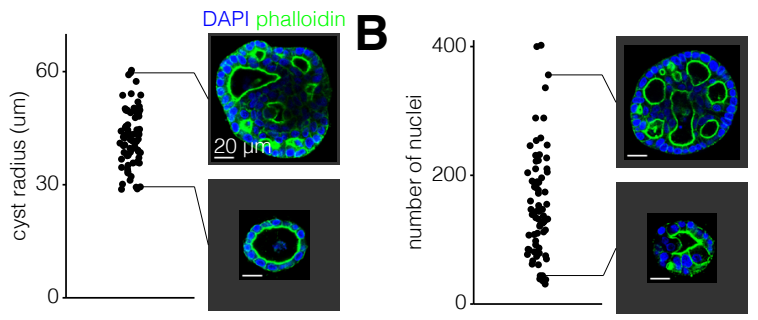

C

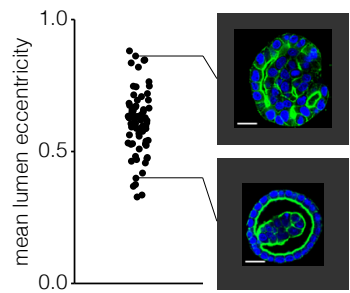




\section{Supplemental Figure 6: Examples MDCK cysts with high and low values for cyst morphological features.}
A. Cyst radius for 7-11 day old MDCK cysts with example images.
B. Number of nuclei for 7-11 day old MDCK cysts with example images.
C. Mean lumen eccentricity for 7-11 day old MDCK cysts with example images. 
bioRxiv preprint doi: https://doi.org/10.1101/2021.01.08.425947; this version posted January 8, 2021. The copyright holder for this preprint (which was not certified by peer review) is the author/funder, who has granted bioRxiv a license to display the preprint in perpetuity. It is made available under aCC-BY 4.0 International license.

\section{Supplemental Figure 7}

A

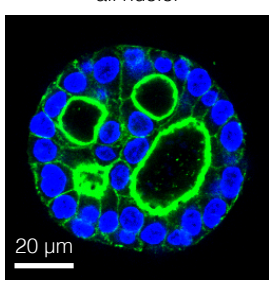

peripheral nuclei

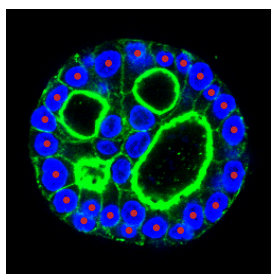

B

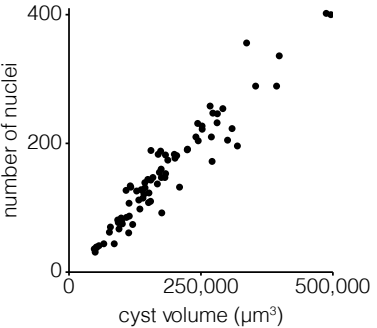

C

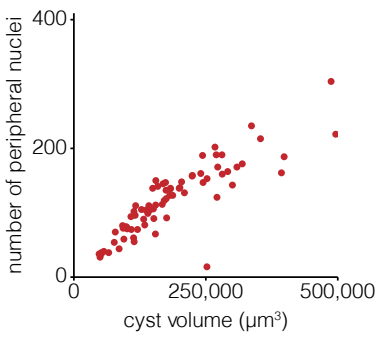

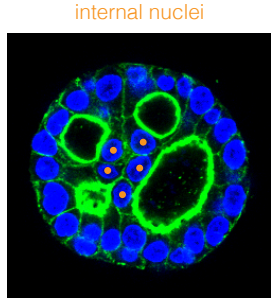

D

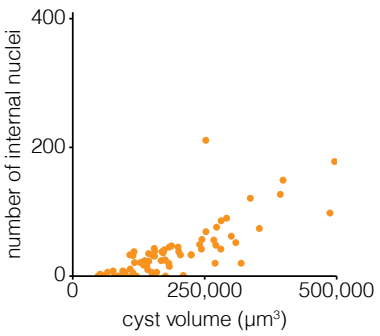




\section{Supplemental Figure 7: Peripheral scale sublinearly and internal nuclei scale superlinearly with cyst volume.}

A. Example MDCK cysts with peripheral nuclei annotated with a red dot and internal nuclei annotated with an orange dot.

B. Number of nuclei versus cyst volume for 7-11 day old MDCK cysts.

C. Number of peripheral nuclei versus cyst volume for 7-11 day old MDCK cysts.

D. Number of internal nuclei versus cyst volume for 7-11 day old MDCK cysts. 
bioRxiv preprint doi: https://doi.org/10.1101/2021.01.08.425947; this version posted January 8, 2021. The copyright holder for this preprint (which was not certified by peer review) is the author/funder, who has granted bioRxiv a license to display the preprint in perpetuity. It is made available under aCC-BY 4.0 International license.

\section{Supplemental Figure 8}

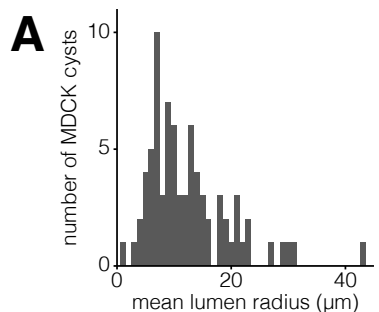


bioRxiv preprint doi: https://doi.org/10.1101/2021.01.08.425947; this version posted January 8, 2021. The copyright holder for this preprint

(which was not certified by peer review) is the author/funder, who has granted bioRxiv a license to display the preprint in perpetuity. It is made available under aCC-BY 4.0 International license.

Supplemental Figure 8: MDCK cysts may have a minimum size for lumens.

A. Histogram (with a bin width of $1 \mathrm{um}$ ) of mean lumen radius for MDCK cysts cultured for 7-11 days. 
bioRxiv preprint doi: https://doi.org/10.1101/2021.01.08.425947; this version posted January 8, 2021. The copyright holder for this preprint (which was not certified by peer review) is the author/funder, who has granted bioRxiv a license to display the preprint in perpetuity. It is made available under aCC-BY 4.0 International license.

\section{Supplemental Figure 9}

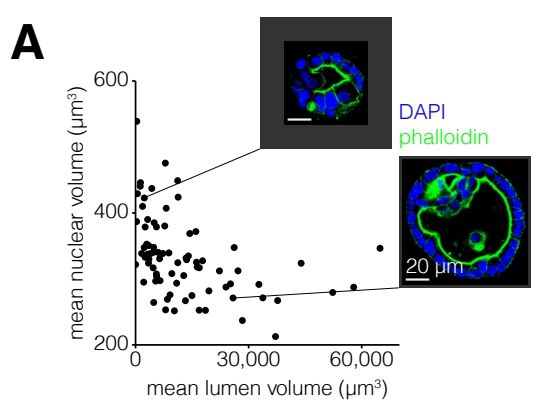


bioRxiv preprint doi: https://doi.org/10.1101/2021.01.08.425947; this version posted January 8, 2021. The copyright holder for this preprint

(which was not certified by peer review) is the author/funder, who has granted bioRxiv a license to display the preprint in perpetuity. It is made available under aCC-BY 4.0 International license.

Supplemental Figure 9: Mean nuclear size is inversely correlated with mean lumen size.

A. Mean nuclear volume versus mean lumen volume for 7-11 day old MDCK cysts with example images. 
bioRxiv preprint doi: https://doi.org/10.1101/2021.01.08.425947; this version posted January 8, 2021. The copyright holder for this preprint (which was not certified by peer review) is the author/funder, who has granted bioRxiv a license to display the preprint in perpetuity. It is made available under aCC-BY 4.0 International license.

\section{Supplemental Figure 10}
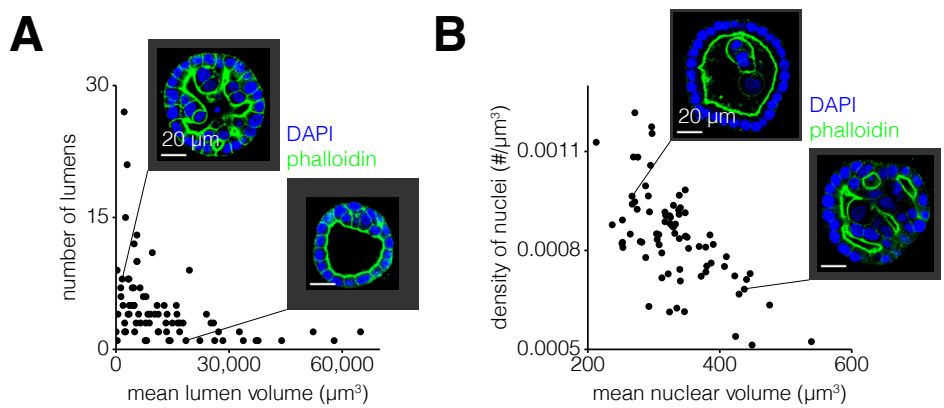


\section{Supplemental Figure 10: The number of lumens and nuclei are inversely correlated with their mean volume.}

A. Number of lumens versus mean lumen volume for 7-11 day old MDCK cysts with example images.

B. Density of nuclei versus mean nuclear volume for 7-11 day old MDCK cysts with example images. 
bioRxiv preprint doi: https://doi.org/10.1101/2021.01.08.425947; this version posted January 8, 2021. The copyright holder for this preprint (which was not certified by peer review) is the author/funder, who has granted bioRxiv a license to display the preprint in perpetuity. It is made available under aCC-BY 4.0 International license.

\section{Supplemental Figure 11}

A

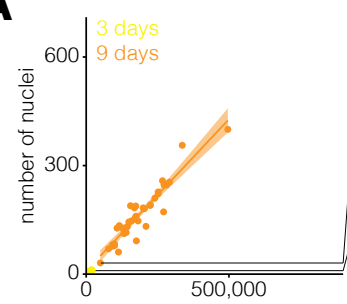

cyst volume $\left(\mu \mathrm{m}^{3}\right)$

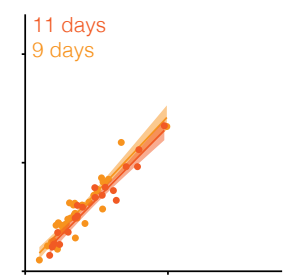

DAPI phalloidin
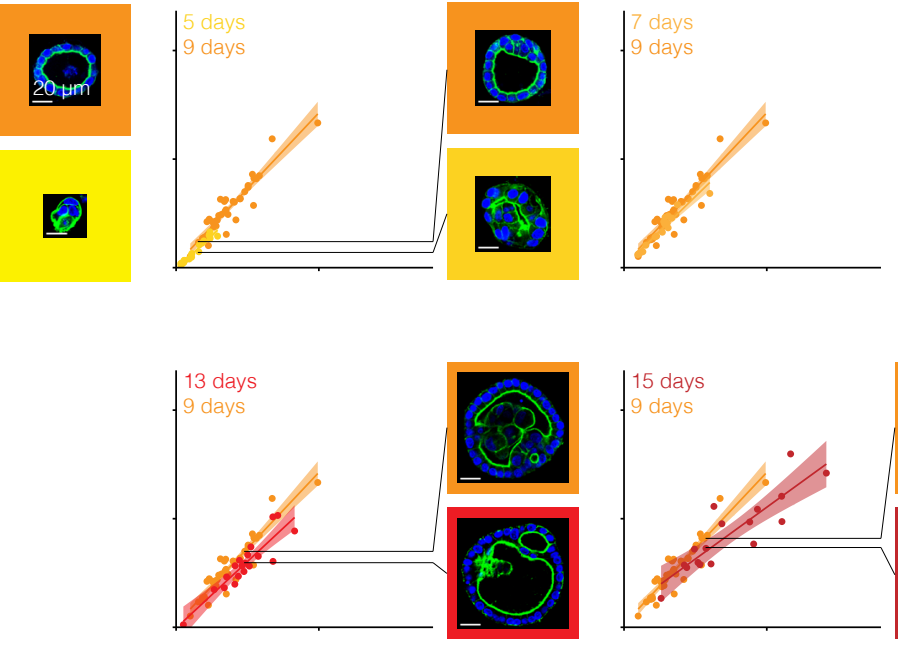
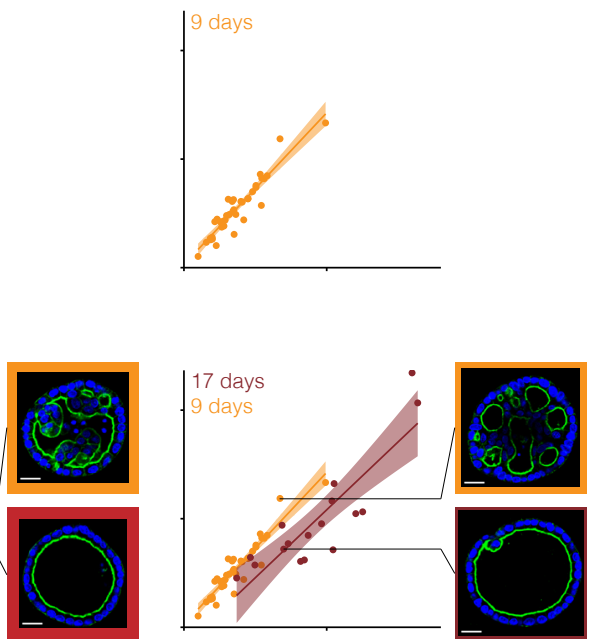


\section{Supplemental Figure 11: Constraint on number of nuclei and cyst volume varies with MDCK cyst age.}

A. Number of nuclei versus cyst volume for MDCK cysts of each age. Each age is represented by one color, and 9 day old MDCK cysts are repeated on each graph for reference. The line represents the line of best fit and the shaded area represents the 95\% confidence interval. Example MDCK cysts of different ages with approximately the same volume and different numbers of nuclei are shown. 
bioRxiv preprint dol: https://doi.org/10.1101/2021.01.08.425947; this version posted January 8,2021 . The copyright holder for this preprint

(which was not certified by peer review) is the author/funder, who has granted bioRxiv a license to display the preprint in perpetuity. It is made available under aCC-BY 4.0 International license.

Supplemental Figure 12
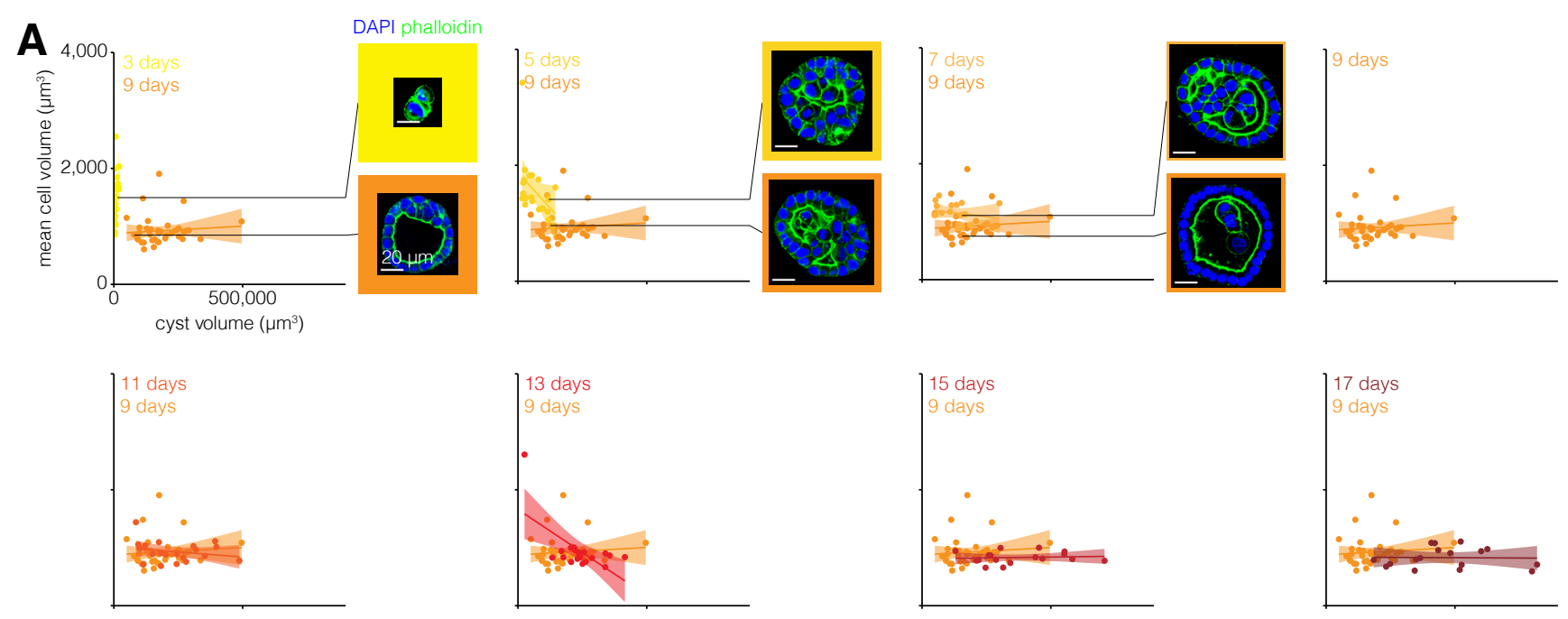


\section{Supplemental Figure 12: Constraint on cell volume and cyst volume varies with MDCK cyst age.}

A. Mean cell volume versus cyst volume for MDCK cysts of each age. Each age is represented by one color, and 9 day old MDCK cysts are repeated on each graph for reference. The line represents the line of best fit and the shaded area represents the 95\% confidence interval. Example MDCK cysts of different ages with approximately the same cyst volume and different mean cell volume are shown. 
bioRxiv preprint doi: https://doi.org/10.1101/2021.01.08.425947; this version posted January 8, 2021. The copyright holder for this preprint (which was not certified by peer review) is the author/funder, who has granted bioRxiv a license to display the preprint in perpetuity. It is made available under aCC-BY 4.0 International license.

\section{Supplemental Figure 13}

A

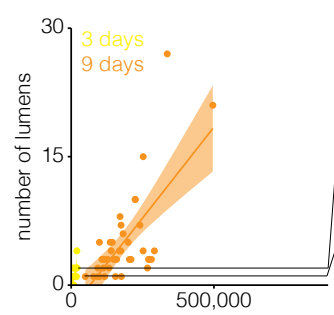

cyst volume $\left(\mu \mathrm{m}^{3}\right)$

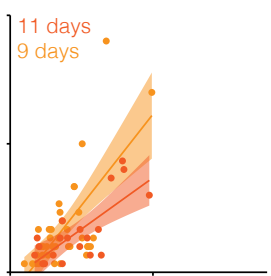

DAPI phalloidin
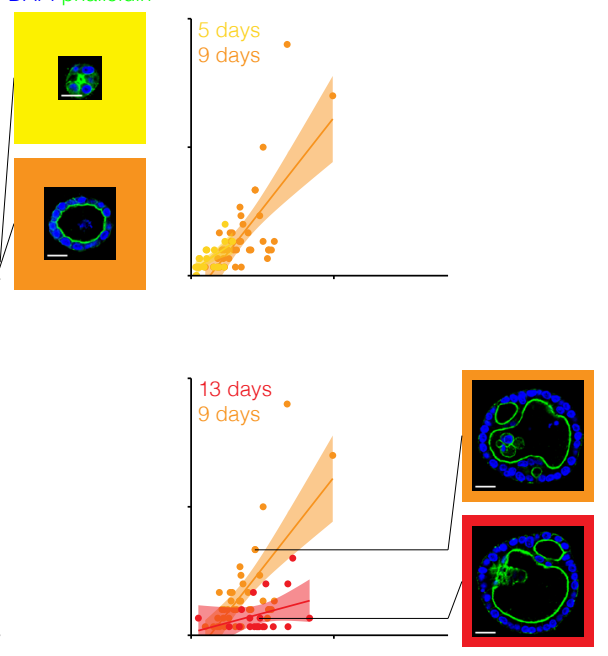
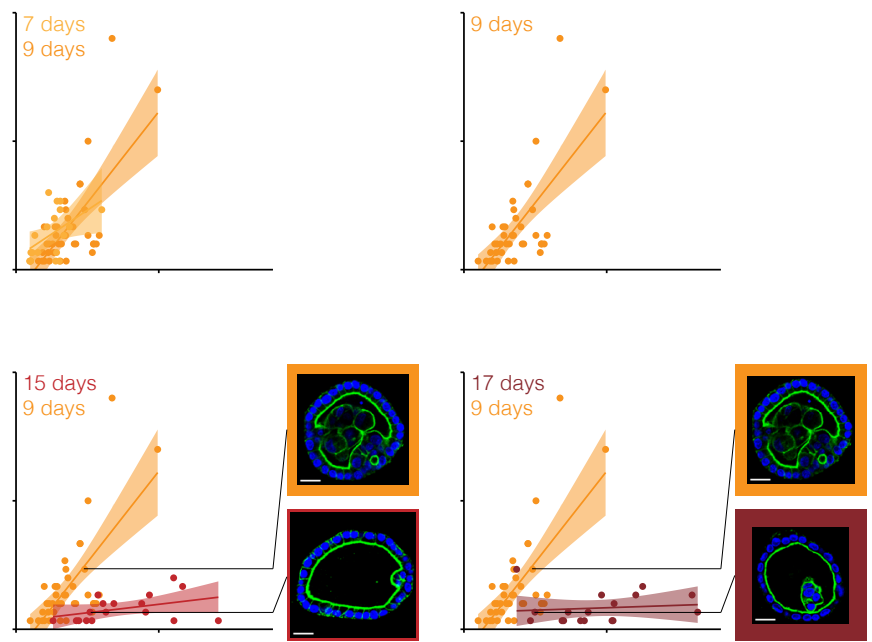


\section{Supplemental Figure 13: Constraint on number of lumens and cyst volume varies with MDCK cyst age.}

A. Number of lumens versus cyst volume for MDCK cysts of each age. Each age is represented by one color, and 9 day old MDCK cysts are repeated on each graph for reference. The line represents the line of best fit and the shaded area represents the 95\% confidence interval. Example MDCK cysts of different ages with approximately the same cyst volume and different numbers of lumens are shown. 
bioRxiv preprint doi: https://doi.org/10.1101/2021.01.08.425947; this version posted January 8, 2021. The copyright holder for this preprint (which was not certified by peer review) is the author/funder, who has granted bioRxiv a license to display the preprint in perpetuity. It is made available under aCC-BY 4.0 International license.

\section{Supplemental Figure 14}
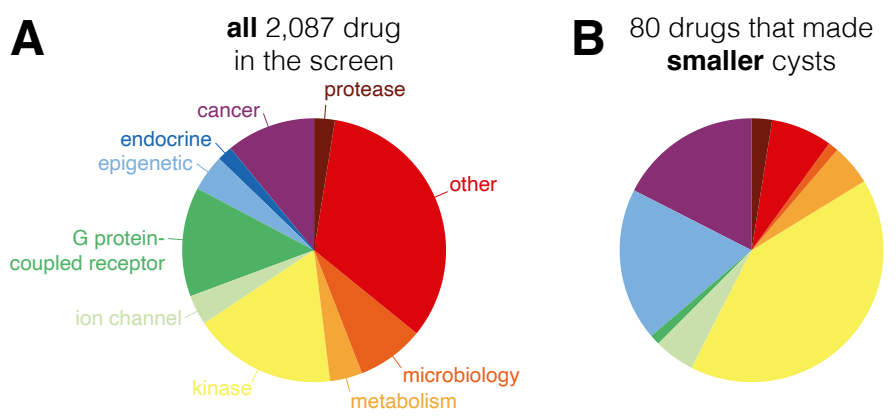
C 78 drugs that made larger cysts

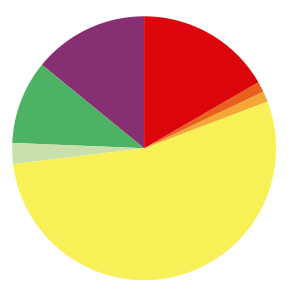


bioRxiv preprint doi: https://doi.org/10.1101/2021.01.08.425947; this version posted January 8, 2021. The copyright holder for this preprint

(which was not certified by peer review) is the author/funder, who has granted bioRxiv a license to display the preprint in perpetuity. It is made available under aCC-BY 4.0 International license.

Supplemental Figure 14: Proportions of drug categories for drug screen.

A. Proportion of drugs categories for all drugs screened.

B. Proportion of drug categories amongst drugs found to decrease cyst area.

C. Proportion of drug categories amongst drugs found to increase cyst area. 
bioRxiv preprint doi: https://doi.org/10.1101/2021.01.08.425947; this version posted January 8, 2021. The copyright holder for this preprint (which was not certified by peer review) is the author/funder, who has granted bioRxiv a license to display the preprint in perpetuity. It is made available under aCC-BY 4.0 International license.

\section{Supplemental Figure 15}

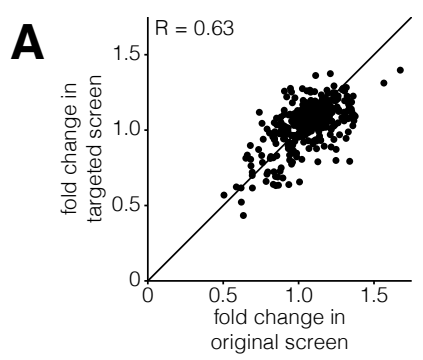


bioRxiv preprint doi: https://doi.org/10.1101/2021.01.08.425947; this version posted January 8, 2021. The copyright holder for this preprint

(which was not certified by peer review) is the author/funder, who has granted bioRxiv a license to display the preprint in perpetuity. It is made available under aCC-BY 4.0 International license.

Supplemental Figure 15: Correlation between original and targeted drug screen. A. For drugs screened in replicate (1/7th of all drugs screen), the fold change in the targeted screen versus the fold change in the original screen. 
bioRxiv preprint doi: https://doi.org/10.1101/2021.01.08.425947; this version posted January 8, 2021. The copyright holder for this preprint (which was not certified by peer review) is the author/funder, who has granted bioRxiv a license to display the preprint in perpetuity. It is made available under aCC-BY 4.0 International license.

\section{Supplemental Table 1}

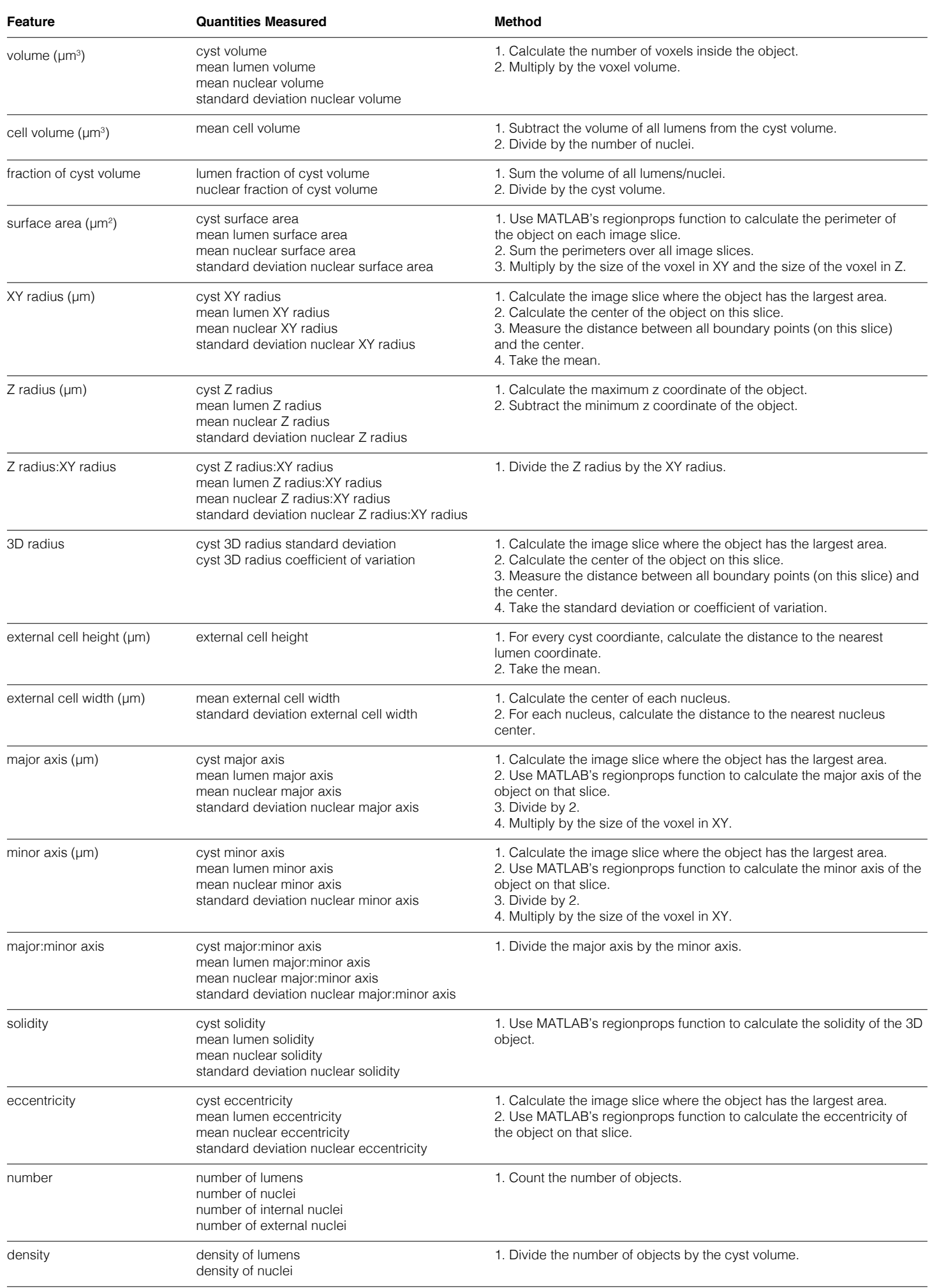


bioRxiv preprint doi: https://doi.org/10.1101/2021.01.08.425947; this version posted January 8, 2021. The copyright holder for this preprint (which was not certified by peer review) is the author/funder, who has granted bioRxiv a license to display the preprint in perpetuity. It is made available under aCC-BY 4.0 International license.

\section{Supplemental Table 1: MDCK Cyst Morphological Features.}


bioRxiv preprint doi: https://doi.org/10.1101/2021.01.08.425947; this version posted January 8, 2021. The copyright holder for this preprint (which was not certified by peer review) is the author/funder, who has granted bioRxiv a license to display the preprint in perpetuity. It is made available under aCC-BY 4.0 International license.

\section{Supplemental Table 2}

\begin{tabular}{ll} 
Drug & Concentrations \\
\hline selinexor & $0.1,0.3 \mu \mathrm{M}$ \\
\hline lapatinib & $40,130,400 \mathrm{nM}$ \\
\hline givinostat & $0.1 \mu \mathrm{M}$ \\
\hline Pl-103 & $0.1,0.3 \mu \mathrm{M}$ \\
\hline idelalisib & $3,10,30 \mu \mathrm{M}$ \\
\hline mardepodect & $0.1,1.0 \mu \mathrm{M}$ \\
\hline sumatriptan succinate & $0.1,0.3,1.0 \mu \mathrm{M}$ \\
\hline Aurora A Inhibitor I & $0.1,0.3,1.0 \mu \mathrm{M}$ \\
\hline orantinib & $0.5,1.6,5.0 \mu \mathrm{M}$ \\
\hline HGF & $5,20 \mathrm{ng} / \mathrm{mL}$
\end{tabular}


bioRxiv preprint doi: https://doi.org/10.1101/2021.01.08.425947; this version posted January 8, 2021. The copyright holder for this preprint (which was not certified by peer review) is the author/funder, who has granted bioRxiv a license to display the preprint in perpetuity. It is made available under aCC-BY 4.0 International license.

Supplemental Table 2: Perturbation Drugs and Concentrations. 
bioRxiv preprint doi: https://doi.org/10.1101/2021.01.08.425947 this version posted January 8, 2021. The copyright holder for this preprint (which was not certified by peer review) is the author/funder, who has granted bioRxiv a license to display the preprint in perpetuity. It is made available under aCC-BY 4.0 International license.

\section{Supplemental Table 3}

\section{Drug}

Indicates used for follow-up analysis

$\underline{\mathrm{PI} 3 \mathrm{~K} / \mathrm{AKT} / \mathrm{mTOR}}$

A66

CZC24832

NU7026

$\checkmark \mathrm{Pl}-103$

PP242

YM201636

CCT128930

MK-2206 2HCl

DNA Damage

Caffeic Acid Phenethyl Ester

VE-822

Capecitabine

Costunolide

Aurora Kinase

$\checkmark$ Aurora A Inhibitor I

CCT137690

CYC116

Bcr-Abl

DCC-2036 (Rebastinib)

GZD824

Nilotinib (AMN-107)

CDK

AT7519

MK-8776 (SCH 900776)

Palbociclib (PD-0332991) HCl

\section{$\underline{\text { RAF/MEK/ERK }}$}

AZ 628

GW5074

SB590885

Adrenergic Receptor

Clorprenaline $\mathrm{HCl}$

Xylazine $\mathrm{HCl}$

Histamine

Cimetidine

Ketotifen Fumarate

JAK

CYT387

Ruxolitinib (INCB018424)

PDE

PF-2545920

Pentoxifylline
S4135

S2516

S2636

S7018

S2893

S1038

S2218

S1219

S2635

S1078

S7414

S7102

S1156

S1319

S1451

S2744

S1171

S2634

S7194

S1033

S1524

S2735

S1116

S2746

S2872

S2220

S1845

S2024

S2219

S1378

S2687

S4345

\section{Selleckchem}

Catalog Number Target(s)
PI3K

PI3K

DNA-PK

PI3K,Autophagy,DNA-PK,mTOR

mTOR,Autophagy

$\mathrm{PI3K}$

Akt

Akt

$\mathrm{NF}-\mathrm{kB}$

ATM/ATR

DNA/RNA Synthesis

Telomerase

Aurora Kinase

Aurora Kinase

Aurora Kinase, VEGFR

Bcr-Abl

Bcr-Abl

Bcr-Abl

CDK

CDK,Chk

CDK

Raf

Raf

Raf

Beta2 receptor

Adrenergic Receptor

Histamine Receptor

Histamine Receptor

JAK

JAK

PDE

PDE 
bioRxiv preprint doi: https://doi org/10.1101/2021.01.08,425947; this version posted January 8, 2021. The copyright holder for this preprint (which was not certified by peer review) is the author/funder, who has granted bioRxiv a license to display the preprint in perpetuity. It is made available under aCC-BY 4.0 International license.

Serotonin

$\checkmark$ Sumatriptan Succinate

Trazodone $\mathrm{HCl}$

S1432

S2582

S1014

S7060

PP1

Unique Targets

Glipizide

Amfenac Sodium Monohydrate

Ferulic Acid

Formononetin

Meprednisone

Mometasone furoate

Penicillin G Sodium

Rifaximin

Thiamet G

Triamcinolone Acetonide

VGX-1027

(-)-Blebbistatin

Cyclopamine

DMXAA (Vadimezan)

Dexamethasone acetate

Fasudil (HA-1077) HCl

Fingolimod (FTY720) HCl

GDC-0152

GSK3787

GW788388

Griseofulvin

Indirubin

Isradipine

Mifepristone

Mubritinib (TAK 165)

AG-1024

PHA-665752

$\mathrm{PX}-4782 \mathrm{HCl}$

SB216763

SKLB1002

Sitaxentan sodium

Sotrastaurin

Thioguanine

VX-745

Thiamine $\mathrm{HCl}$ (Vitamin B1)

Disodium Cromoglycate

Non-Specific Targets

Cabozantinib (XL184, BMS-907351) S1119

Dovitinib (TKI-258, CHIR-258) S1018

Golvatinib (E7050)

NVP-BHG712

Ponatinib (AP24534)

TG101209
S2859

S1715

S4149

S2300

S2299

S1689

S1987

S4160

S1790

S7213

S1628

S7515

S7099

S1146

S1537

S3124

S1573

S5002

$\mathrm{S} 7010$

S8025

S2750

S4071

S2386

$\mathrm{S} 1662$

S2606

S2216

$\mathrm{S} 1234$

S1070

S7612

S1075

S7258

S3034

S2791

S1774

S1458

S3211

S1911

S2202

$\mathrm{S} 1490$

S2692
5-HT Receptor

5-HT Receptor

Src

Src

Potassium channels

COX

glucocorticoid

corticosteroid

antibiotic

RNA polymerase

O-GlcNAcase

corticosteroid

TLR4

ATPase

Hedgehog

VDA

interleukin receptor

ROCK,Autophagy

S1P Receptor

IAP

PPAR

TGF-beta/Smad

Microtubule Associated

GSK-3

Calcium Channel

Estrogen/progestogen Receptor

HER2

IGF-1R

c-Met

HIF

GSK-3

VEGFR

Endothelin Receptor

PKC

DNMT1

p38 MAPK

Vitamin B

antiallergic drug

FLT3,Tie-2,c-Kit,c-Met,VEGFR,AxI FGFR,FLT3,c-Kit,VEGFR,PDGFR VEGFR,c-Met

Raf,Src,Bcr-Abl,VEGFR,Ephrin receptor PDGFR,FGFR,VEGFR,Bcr-Abl JAK,FLT3,C-RET 
bioRxiv preprint doi: https://doi.org/10.1101/2021.01.08.425947; this version posted January 8, 2021. The copyright holder for this preprint

(which was not certified by peer review) is the author/funder, who has granted bioRxiv a license to display the preprint in perpetuity. It is made available under aCC-BY 4.0 International license.

Supplemental Table 3: Hits for Larger MDCK Cysts from Drug Screen, Grouped by Target. 
bioRxiv preprint doi: https://doi.org/10.1101/2021.01.08.425947; this version posted January 8,2021 . The copyright holder for this preprint (which was not certified by peer review) is the author/funder, who has granted bioRxiv a license to display the preprint in perpetuity. It is made available under aCC-BY 4.0 International license.

\section{Supplemental Table 4}

\section{Drug}

\section{Selleckchem}

Catalog Number Target(s)

Indicates used for follow-up analysis

\section{EGFR/HER2}

AEE788 (NVP-AEE788)

AZD8931 (Sapitinib)

Afatinib (BIBW2992)

Canertinib (Cl-1033)

Dacomitinib (PF299804, PF299)

Gefitinib (ZD1839)

$\checkmark$ Lapatinib (GW-572016) Ditosylate

Neratinib (HKI-272)

Pelitinib (EKB-569)

HDAC

AR-42

Belinostat (PXD101)

Entinostat (MS-275)

$\checkmark$ Givinostat (ITF2357)

M344

Mocetinostat (MGCD0103)

PCl-24781 (Abexinostat)

Pracinostat (SB939)

Scriptaid

\section{PI3K/AKT/mTOR}

AZD8055

Everolimus (RAD001)

GDC-0980 (RG7422)

WYE-125132 (WYE-132)

GSK2126458 (GSK458)

INK 128 (MLN0128)

Torin 2

Aurora Kinase

AMG-900

Barasertib (AZD1152-HQPA)

GSK1070916

Hesperadin

PF-03814735

SNS-314 Mesylate

\section{Topoisomerase}

Idarubicin $\mathrm{HCl}$

SN-38

Topotecan $\mathrm{HCl}$

Camptothecin

Mitoxantrone $\mathrm{HCl}$

Teniposide

\section{RAF/MEK/ERK}

\section{AZD8330}

PD0325901

Pimasertib (AS-703026)
S1486

S2192

S1011

S1019

S2727

S1025

S1028

S2150

S1392

S2244

$\mathrm{S} 1085$

S1053

S2170

S2779

S1122

S1090

S1515

S8043

S1555

S1120

S2696

S2661

S2658

S2811

S2817

S2719

S1147

S2740

S1529

S2725

S1154

S1228

S4908

S1231

$\mathrm{S} 1288$

S2485

S1787

S2134

S1036

S1475
HER2,VEGFR,EGFR

HER2,EGFR

EGFR,HER2

EGFR,HER2

EGFR

EGFR

HER2,EGFR

HER2, EGFR

EGFR

HDAC
HDAC
HDAC
HDAC
HDAC
HDAC
HDAC
HDAC
HDAC

mTOR

mTOR

mTOR,PI3K

mTOR

PI3K,mTOR

mTOR

ATM/ATR,mTOR

Aurora Kinase

Aurora Kinase

Aurora Kinase

Aurora Kinase

Aurora Kinase, FAK

Aurora Kinase

Topoisomerase
Topoisomerase
Topoisomerase
Topoisomerase
Topoisomerase
Topoisomerase

MEK

MEK

MEK 
bioRxiv preprint doi: https://doi org/10.1101/2021.01.08.425947; this version posted January 8, 2021. The copyright holder for this preprint (which was not certified by peer review) is the author/funder, who has granted bioRxiv a license to display the preprint in perpetuity. It is made available under aCC-BY 4.0 International license.

TAK-733

Trametinib (GSK1120212)

CRM1

KPT-185

KPT-276

$\checkmark$ KPT-330

Epigenetic Reader Domain

(+)-JQ1

CPI-203

S7110

S7304

S7620

S1248

S2775

S7204

Fosbretabulin Disodium

CDK

Flavopiridol $\mathrm{HCl}$

PHA-793887

S2679

S1487

S1497

Pralatrexate

Methotrexate

Unique Targets

LB42708

MPI-0479605

NSC697923

ONX-0914 (PR-957)

OTX015

Olanzapine

Oligomycin A

RG108

Raltitrexed

Roflumilast

Volasertib (BI 6727)

Tipifarnib

Erastin

A-769662

BIIB021

BMN 673

Cephalomannine

Evodiamine

Flubendazole

Y-320

Guanethidine Sulfate

Nanchangmycin

Acetanilide

Non-Specific Targets

AT9283

Danusertib (PHA-739358)

S7467

S7488

S7142

S7172

S7360

S2493

$\mathrm{S} 1478$

S2821

S1192

S2131

S2235

S1453

S7242

S2697

S1175

S7048

S2408

S2382

S1837

S7516

S4328

S1450

S2538

$\mathrm{S} 1134$
MEK

MEK

CRM1

CRM1

CRM1

Epigenetic Reader Domain

Epigenetic Reader Domain

Epigenetic Reader Domain

Microtubule Associated

Microtubule Associated,Autophagy

Microtubule Associated,Autophagy

CDK

CDK

DHFR

DHFR

Ftase

Kinesin

E2

Proteasome

BET

5-HT Receptor,Dopamine Receptor ATPase

Transferase,DNA Methyltransferase DNA/RNA Synthesis

PDE

PLK

Transferase

Ferroptosis

AMPK

HSP (e.g. HSP90)

PARP

Taxol

antihelminic

JAK,Aurora Kinase,Bcr-Abl

c-RET,FGFR,Bcr-Abl,Aurora Kinase 
bioRxiv preprint doi: https://doi.org/10.1101/2021.01.08.425947; this version posted January 8, 2021. The copyright holder for this preprint (which was not certified by peer review) is the author/funder, who has granted bioRxiv a license to display the preprint in perpetuity. It is made available under aCC-BY 4.0 International license.

\section{Supplemental Table 4: Hits for Smaller MDCK Cysts from Drug Screen, Grouped} by Target. 